\title{
KOLIKO STUDENTI KATOLICI U BIH POZNAJU SVOJU, A KOLIKO RELIGIJU SVOJIH SUSJEDA
}

\section{Sažetak}

Religijska samoidentifikacija stanovnika Bosne i Hercegovine (popis 2013.). U Bosni i Hercegovini se ne susreću različite religije, već građani s različitim religijskim identitetima. Nakon rata 1991.-1995. trebalo je obnoviti međusobno porušene mostove. Zato je potrebno znanje i o sebi i svom religijskom identitetu, ali i o drugima i njihovim religijskim identitetima. U radu će biti riječi o tome koliko studenti katolici u Bosni i Hercegovini imaju znanja o svojoj religiji (katoličanstvu) i o religiji svojih susjeda (muslimana, pravoslavnih, židova). Da li se više razumijemo ili mrzimo, što se više poznajemo? O uzorku. Kako stoji s religioznošću studenata katolika (vjerska naobrazba; poznavanje abrahamskih religija; poznavanje najrasprostranjenije kršćanske molitve, najpoznatijeg kršćanskog blagdana; poznavanje simbola svoje religije). Analiza podataka o tome koliko studenti katolici poznaju svoju religiju. Može li se religioznost studenata mjeriti odlaskom u crkvu? Posjeduju li Bibliju; je li im poznato kako se nazivaju dva dijela Biblije; vjerovanje u Boga, dušu, zagrobni život, raj ... Što znaju o Jeruzalemu, Deset zapovijedi, evanđeljima, franjevcima u BiH, religijskim vođama. Drugi dio rada analizira kako studenti katolici poznaju religiju svojih susjeda: poznavanje židovske religije, islama, pravoslavlja i ostalih religija u BiH. Što studenti katolici misle o ateistima? Pokazatelji (ne)uvažavanja različitosti. Iskustvo života s pripadnicima drugih religija. Kako katolike doživljavaju studenti muslimani, a kako studenti pravoslavci. Zaključak. ateizam.

Ključne riječi: studenti, religija, katoličanstvo, pravoslavlje, islam, židovska religija,

\section{Uvod}

$\mathrm{Na}$ popisu stanovništva 2013. godine, 96,6 \% državljana Bosne i Hercegovine se samoodredilo kao muslimani, pravoslavni i katolici. Malo je zemalja u Europi, a i u svijetu, koje imaju toliko visok postotak religijske samoidentifikacije stanovništva. Za te podatke moglo bi se reći da je mnogo vjernika ne po vjerovanju, već po pripadnosti ("katolik sam"; "pravoslavni sam"; "musliman sam"). Analitičari uobičajeno kažu kako se u Bosni i Hercegovini susreću (ponekad i sukobljavaju) tri religije (židovska, kršćanstvo i islam) i na njima četiri zasnovane konfesije (Jevrejska zajednica, Katolička i Srpska pravoslavna Crkva te Islamska zajednica). Međutim, ne 
susreću se u Bosni i Hercegovini religije (niti na njima zasnovane konfesije), niti se one sukobljavaju, niti mire. Susreću se građani ove države, pripadnici različitih religija (i konfesija), oni se sukobljavaju zloupotrebljavajući svoju religijsku (i konfesionalnu) pripadnost. Često je to i zbog nedovoljnog znanja i o sebi i o drugima. I o svojoj religiji (i konfesiji) i religiji svoga susjeda. Naravno, ne isključujemo mogućnost da u tim sukobljavanjima mogu određenu ulogu imati i njihove konfesije.

Svjedočili smo tome i devedesetih godina prošlog stoljeća: sukobi za koje bismo teško mogli reći da su u njima bile "nevine ruke" barem triju konfesija sa najvećim brojem sljedbenika. A onda je nastupilo "postkonfliktno doba" (bolje reći "postratno doba") u kojem je valjalo, i valja, obnavljati međusobno porušene mostove, graditi pomirenje i mirnu koegzistenciju. A da bi to bilo moguće, potrebno je da građani, osobito mladi, imaju znanja i o svojoj i o religiji svojih susjeda. U ovom tekstu bit će riječi o tome koliko studenti, koji za sebe izjavljuju da su katolici, znaju o svojoj (katoličkoj) religiji, ali i o religiji svojih susjeda (židova, muslimana, pravoslavnih).

Prisjetimo se da su u Bosni i Hercegovini sela tradicionalno grupirana po konfesionalnoj pripadnosti njihovih stanovnika (katoličkoj, islamskoj, pravoslavnoj), u varošima su kvartovi bili podijeljeni na muslimanski (u pravilu centar grada, uz rijeku), latinski, pravoslavni, židovski. Vjenčanje i zajednički život sa osobom izvan svoje konfesije smatrano je, u najmanju ruku, nedoličnim. To je trajalo sve do izgradnje novih gradova i gradskih četvrti u vrijeme socijalizma kad su u iste zgrade, pa i ulaze, useljavali ljudi svih konfesija i svjetonazora. U takvim okolnostima rastao je broj bikonfesionalnih i binacionalnih brakova. Veliki urbani centri bili su naklonjeni pluralizmu. U gotovo svim gradovima u Bosni i Hercegovini u to vrijeme mogla su se pronaći etnička i religijska (konfesionalna) raznolikost (Stanley, 2018). Danas, znatno manje.

Za razliku od postsocijalističkog perioda, u socijalizmu su se manje iskazivali neki vidovi religioznosti: odlazak u crkvu/džamiju; manji broj onih koji su iskazivali svoju religijsku samoidentifikaciju; smanjen utjecaj religija i religijskih zajednica na život građana. Zadržani su više sljedeći vidovi iskazivanja religioznosti: krštenje i/ili obrezivanje djece; brak se sklapao i uz religijske ceremonijale; obilježavanje značajnijih religijskih blagdana, pokopi uz religijski ceremonijal. Te vidove religioznosti više su iskazivale marginalne društvene grupe, te one s nižim obrazovnim i socijalnim statusom.

Danas je religijska situacija sasvim drugačija. Zato je potrebno međusobno poznavanje religijskih vjerovanja i tradicija svojih susjeda. Naravno, 
ne preuveličavajući značaj tog poznavanja. Naime, stvoren je mit o tome da što se više poznajemo da se više i razumijemo. Ili se, možda, više mrzimo što se više poznajemo? Također, upitan je i mit o tome da što su ljudi obrazovaniji (kao studenti u našem istraživanju) to su tolerantniji: "Nemačka je bila najobrazovanija nacija u Evropi, a izazvala je dva svetska rata sa neviđenim zverstvima", piše Šušnjić (2018: 12). "Srbi i Hrvati se sve manje poznaju, pa o drugima često govore iz vlastitih stereotipa i predrasuda." (Jović, 2017: 338). Možda je takva situacija i sa pravoslavnima, katolicima i muslimanima u Bosni i Hercegovini. U vrijeme "digitalnog društva" u kojem je moguće doći do raznoraznih informacija o Drugom (osobito o Drugom s kojim se živi u zajedničkoj domovini) ne znati o njemu ništa, ili gotovo ništa - znak je nezainteresiranosti za Drugoga, znak samodovoljnosti sa "Mi".

Sve one koji su se u popisu 2013. godine (pa i u našem istraživanju) samoodredili kao vjernici mogli bismo grupirati u nekoliko socioloških tipova vjernika:

a) "Statistički" katolik/pravoslavac/musliman - u popisu stanovništva, pri anketiranju, samoodređuje se i kao katolik/pravoslavac/musliman. ${ }^{4}$ Inače, u svim ostalim situacijama živi “zaboravljeno" kršćanstvo/ islam.

b) Pored crkvenog i necrkvenog tipa vjernika, moglo bi se govoriti i o “distanciranom" vjerniku: čovjek treba Crkvu samo za tri slučaja: krštenje, vjenčanje i pokop.

c) "Kulturološki vjernik", onaj koji je katolik, pravoslavni, musliman po katoličkoj, pravoslavnoj, muslimanskoj kulturi, a ne po prakticiranju religije (davanje djeci biblijskih/kur'anskih imena; prihvaćanje nekih fraza religijskog porijekla kao "Ako Bog da"; "Bože sačuvaj"; "S Bogom"...).

d) Oni kojima religija (konfesija) dođe kao folklorni znak hrvatstva, srpstva, bošnjaštva.

e) Tip vjernika "kojima su jedina veza s vjerom bili ime i prezime te više navika nego potreba slavljenje Bajrama s familijom." (Imamović, 2018: 105), ili Božića i Vaskrsa s obitelji.

\footnotetext{
4 “U Francuskoj, na primer, ljudi se većinom izjašnjavaju kao katolici, ali to u stvari nisu. Oni su, zapravo, ono što je ostalo od katolicizma. Katolici su poreklom, i po tradiciji, ako hoćeš. Ali nisu pravi katolici. Biti katolik, to ne znači samo biti kršten i neodređeno verovati u Boga; to podrazumeva i određeni način života", piše francuski književnik Florian Zeller u romanu Opčinjenost najgorim (Zeler, 2015: 123).
} 
Što se tiče samog uzorka, u gradu je živjelo $249(49,9 \%)$ ispitanih studenata, prigradskom naselju 103 (20,6\%), te na selu $72(14,4 \%)$. Već godinama, gledajući spolnu pripadnost studenata, može se reći da su studiji postali “ženski studiji”. Pokazalo je to i ovo istraživanje. Studentica je bilo 52,3\%, studenata 31,9 \% (ostali se nisu izjasnili). Među studentima društvenih nauka više je studentica (54,2 \%), u odnosu na tehničke fakultete (tamo je 53,1 \% studenata). I u ovom istraživanju se pokazalo da žene više sudjeluju u religijskoj praksi, više vjeruju, izraženija im je religijska samoidentifikacija, više prakticiraju u individualnoj molitvi. Ne proizlazi to iz toga jer su one Žene već iz njihovog socijalnog statusa (od obitelji do društva, u globalu). Je li religija kompenzacija za taj njihov socijalni status?

Iz Republike Srpske bilo je 105 ispitanika (21,0 \%). Istraživanjem je, u kontrolnoj grupi, obuhvaćeno 8 studenata Franjevačke teologije i 10 studenata Katoličkog bogoslovnog fakulteta u Sarajevu (ukupno 18 studenata katoličke teologije), 10 studenata Fakulteta islamskih nauka u Sarajevu i 10 studenata Pravoslavne teologije u Foči.

\section{$* * *$}

Kako to izgleda s religioznošću studenata katolika? Pođimo od vjerske naobrazbe. Svoje prvo upoznavanje s religioznošću dijete stječe u obitelji. Roditelji ga uče kako se odnositi prema "svetom", koji je znak njegove religijske "pripadnosti” i sl. Tek kasnije, potpunije pouke steći će kroz vjeronauk. Dakle, vjeronauka je pouka u vjeri koja se daje novim vjernicima, i onima koji nisu dovoljno upućeni u vjersko učenje. Riječ je o puci u simbolima vjere, njenom glavnom učenju, molitvama i sl. U Socijalističkoj Republici Bosni i Hercegovini nije se izvodila u javnim školama već u prostorijama religijskih zajednica. U postsocijalističkoj Bosni i Hercegovini izvodi se, uglavnom, u javnim školama. ${ }^{5}$

Uvijek kad pred Bajram (ili ramazan) u novinama pročitam da je pred neku džamiju bačena svinjska glava ili da se na džamijskim zidovima ispisani uvjerljivi grafiti; pred Vaskrs oskrnavljena neka pravoslavna ili pred Božić katolička crkva, zapitam se čemu djecu uče na vjeronauku. (Zapitat ću se to

\footnotetext{
${ }^{5}$ Jedno istraživanje u Francuskoj pokazalo je da samo 4 \% roditelja svrstava religiozno vjerovanje među značajne kvalitete koje treba podsticati kod djece (Ervije-Leže, 2009: 179).
} 
više puta analizirajući i podatke iz našeg istraživanja). Počinitelji tih djela, u pravilu, su mladići koji su, u 90 \% slučajeva, pohađali vjeronauk u javnim školama. Čemu ih tamo uče? Kakvoj “toleranciji”, međusobnom poštovanju i uvažavanju? Manje je, gotovo nikako, takvih pojava bilo sedamdesetih ili osamdesetih godina prošlog stoljeća kad se u javnim školama nije izučavao vjeronauk. Ovim ne želim reći da ih tamo nagovaraju da čine skrnavljenje vjerskih objekata Drugoga, već da ih ne uče - bar ne dovoljno - poštovanju Drugoga i drugačijeg. ${ }^{6}$

Svi ispitanici koji su se samoodredili kao katolici pohađali su vjeronauk (100 \%). Ako gledamo njihovu spolnu strukturu, 91,2 studentica i 89,9\% studenata je pohađalo vjeronauk (1,3\% više studentice).

Već smo rekli da se vjeronauka, od 90-ih godina prošlog stoljeća, pomjerila iz džamije/crkve u javne škole. Potvrdilo je to i naše istraživanje: Od svih ispitanika, 88,4 \% izjasnilo se da su pohađali vjeronauku u javnoj školi, a samo 4,2 \% pri religijskoj zajednici. Kod studenata katolika situacija je nešto specifičnija: 83,9 \% ih je pohađalo vjeronauk u javnoj školi, 16,1 \% pri religijskoj zajednici. Izgleda da je školski vjeronauk bio više zastupljen kod pravoslavnih (96,5\%) i muslimana (90, $8 \%$ ).

Teolozi, psihijatri, liječnici često ističu da onima koji vjeruju njihova vjera olakšava mnoge životne situacije (bolest, tuga, smrt, razne traume ...). ${ }^{7}$ Studenti katolici $(51,8 \%)$ smatraju da su katoličanstvo, pravoslavlje i islam dobar okvir za vjeru i važan pozitivan društveni faktor i korektor (isto mišljenje imalo je 43,4 \% muslimana i 34,5 \% pravoslavnih). Odmah iza toga, 26,8 \% ih navodi da su te religije, unatoč institucionalnoj krizi i političkoj zloupotrebi glavni izvor smisla i društvenih vrednota (muslimani 10,8 $\%$ i pravoslavni $14,8 \%$ ). Samo po 3,6 \% studenata katolika smatra da religije nisu prostor za njih (14,3 \% muslimana i $12,0 \%$ pravoslavnih), te da su dominirajuće religije u Bosni i Hercegovini potrošile svoj moralni kredibilitet pa će sve dublje gubiti povjerenje (ovo smatra 3,6 \% studenata katolika, 7,7 \% studenata pravoslavnih i 3,6 \% studenata muslimana).

Ispitanike smo zamolili da navedu koje su to "abrahamske" (monoteističke religije). Riječ je o religijama koje imaju zajedničko podrijetlo od Abrahama/

\footnotetext{
${ }^{6}$ Je li vjeronauk zauzima visoko (ili nisko) mjesto na popularnosti predmeta među učenicima? Neka istraživanja vršena u Njemačkoj pokazuju nizak stupanj popularnosti obavezujućeg školskog vjeronauka. Susret mladih sa suvremenim problemima religioznosti možda prevazilazi ono što im pruža konfesionalni školski vjeronauk. U nekim Njemačkim pokrajinama u škole se uvodi znanost o religiji(ama). 7 "Ljudima od vjere lakše je. Kakvu god svinjariju počinili, od pelješenja nečijeg novčanika do ubojstva. Bog je tu da im oprosti grijehe. Vjernici zabacuju teško breme grijeha i rasterećeni kreću dalje" (Ugrešić, 2019: 97).
} 
Ibrahima (židovska religija, kršćanstvo, islam, bahaizam). Zajednička im je odlika bila najava egzaltirane etike. Drugo, one su potisnule kult božica - ostao je samo jedan Bog. Zato ih nazivamo i monoteističkim religijama. ${ }^{8}$ Studenti katolici informiraniji su o tome od svojih kolega pripadnika druge dvije konfesije: $67,9 \%$ studenata katolika zna koje religije spadaju u abrahamske (28,3\% muslimana, 43,7 \% pravoslavnih, 40,6 \% onih koji za sebe kažu "nisam vjernik"). Studenti društvenih nauka su daleko više upoznati s tim koje religije spadaju u abrahamske $(42,7 \%)$ u odnosu na studente tehničkih nauka (6,1\%). Evo i nekih od pogrešnih ili nepotpunih odgovora: budizam; hrišćani i muslimani; hrišćanstvo, islam, budizam; islam, pravoslavlje, katolicizam; islam, "zoroastrejstvo"; judaizam, hinduizam, taoizam, itd.

U svakoj od religija našeg okruženja, molitva zauzima važan obredni čin. Ona može biti individualna, osobna, i kolektivna, grupna. Sadrži se od vršenja propisanih radnji i/ili izgovaranja točno određenih riječi. Pri tom se vjernik može služiti i nekim pomagalom (brojanice u kršćanstvu, tespih u islamu...). Neki autori molitvu dijele na usmenu, pisanu, meditativnu ... Bez obzira o kojoj vrsti molitve je riječ, ona je čin samoidentifikacije sa zajednicom. Svi izgovaraju iste riječi molitve (kod židova u sinagogi mora biti najmanje 10 odraslih osoba da bi molitva bila valjana) i na isti način (podignutih ili sklopljenih ruku, naklonom tijela ...). Za mene kao ateistu, uvijek se otvaralo pitanje slavi li se Boga molitvom, ili poštivanjem njegovih poruka danih u svetim spisima? ${ }^{9}$ Izgleda da se velik broj vjernika ne "opterećuje" tim pitanjem.

"Oče naš” je najrasprostranjenija kršćanska molitva koja počinje tim riječima, a koristi se individualno, ili skupno pri bogosluženju (Mt 6,9-13). Vjeruje se da ju je sastavio Krist i izgovara se svaki dan. Prvi kršćani znali su samo za ovu molitvu. Provjerili smo kod ispitanika znaju li koja je najpoznatija kršćanska molitva. Da je to "Oče naš" zna 76,8 \% studenata katolika (68,5 \% muslimana, 86,5 \% pravoslavnih, 78,1 \% “nisam vjernik”). Točan odgovor dalo je 77,3 \% studenata društvenih i 59,2 \% studenata tehničkih nauka. Pomalo je iznenađujuće da je to znalo samo 81,6 \% studenata teologije. Također, iznenađujuće je da to više od katolika znaju oni koji za sebe kažu "nisam vjernik" (78,1 \%) i studenti pravoslavni (86,5 \%). Kad usporedimo nacionalnu pripadnost ispitanika i točan odgovor na ovo pitanje, vidimo da je 88,2 Srba znalo točan odgovor, 78,8 i Hrvata i 68,1 \% Bošnjaka.

\footnotetext{
8 “Čemu uzbuna? Zar židovstvo, kršćanstvo i islam nisu tri sestrinske, jednakovrijedne, objavljene, povijesne, jednobožačke abrahamske religije?" (Markešić, 2012: 100)

9 "Moram vam reći da se molim iako ne vjerujem", kaže jedan od likova u Gogoljevom romanu Mrtve duše (2004: 293).
} 
Među elementarno poznavanje kršćanstva spadalo bi i znanje o tome koji je najznačajniji kršćanski blagdan. O nedovoljnom poznavanju kršćanstva govori i to da se često Božić navodi kao najvažniji kršćanski blagdan. Od svih ispitanika (499), samo ih je 32,06 \% znalo da je Uskrs/Vaskrs najveći kršćanski blagdan kojim se obilježava uskrsnuće Isusa Krista. To zna 92,9 \% studenata katolika (12,0 \% muslimana, 41,5 \% pravoslavnih, 37,5 \% "nisam vjernik"). Opet su nam studenti teologije priredili iznenađenje: tek 65,8 \% ih je znalo točan odgovor. Dakle, ni svi studenti katoličke i pravoslavne teologije nisu znali točan odgovor (u uzorku kontrolne grupe bilo ih je 72,9 \%). Kad pogledamo nacionalnu pripadnost ispitanika, vidimo da je točan odgovor znalo 11,6 \% Bošnjaka, 92,3 \% Hrvata i 45,2 \% Srba.

Treća elementarna činjenica o poznavanju kršćanstva jeste odgovor na pitanje o simbolu te religije. Križ/krst je simbol kršćanstva sastavljen od dva kraka koji se spajaju pod pravim kutom. Njime su ukrašene crkve, zvonici, vjernici ga nose u obliku privjeska i tetoviraju po tijelu. Otud ne iznenađuje da je $83,97 \%$ ispitanika ispravno odgovorilo na pitanje "Da li znate koji je simbol kršćanstva?" To zna 94,7 \% studenata katolika (78,5 \% muslimana, $88,7 \%$ pravoslavnih i $87,5 \%$ "nisam vjernik"), te $97,3 \%$ studenata teologije. Kad usporedimo odgovor na ovo pitanje i nacionalnu pripadnost ispitanika vidimo da je odgovor znalo 79,3 \% Bošnjaka, 99,5 \% Hrvata i 88,4 \% Srba.

\section{Samopoznavanje}

Slijedi analiza podataka o tome koliko studenti katolici, prema drugim pokazateljima, poznaju svoju religiju (konfesiju)?

Možemo konstatirati da religija danas nema (kao što je nekad imala) utjecaja na medicinu, gospodarstvo, umjetnost i slične aktivnosti, ali itekako sudjeluje u određenju tko smo "mi", a tko su "oni". Ona ujedinjuje ljude, istovremeno ih razdvajajući od susjeda. Valerie Tarico izdvojila je 12 groznih ideja na kojima možemo zahvaliti religiji: 1. izabrani ljudi, 2. heretici, 3. sveti ratovi, 4. bogohuljenje, 5. glorificiranje patnje, 6. genitalno sakaćenje, 7. krvna žrtva, 8. pakao, 9. karma, 10. vječni život, 11. muško vlasništvo nad ženskom plodnošću, 12. biblioprokletstvo ili obožavanje Knjige.

Religija je za sociologa i granica. Ona odvaja pripadnike jedne religije (ili konfesije) od pripadnika drugih religija (ili konfesija). To je, uglavnom, stabilna granica. Ali ona, kao i svaka granica, može dovoditi i do međusobnih napetosti. Mogli bismo navoditi primjere napetog suživota religijskih i etničkih zajednica i u starim i u novim državama diljem svijeta (Smith, 2003). 
Riječ je o serijama antagonizama, koji su uplovljavali i u naše vlastite negacije (Krleža, 2009: 130). Da bi se ti antagonizmi izbjegli potrebno je biti slijep za razlike, vidovit za sličnosti, kako je pisao pjesnik Oskar Davičo (Prema: Ivanji, 2018: 368). Treba se učiti na poštovanje raznolikosti. Njemački lanac trgovina Lidl s nekih svojih proizvoda iz Grčke i Italije na slikama crkava brisao je križeve, jer, kako objašnjavaju, žele poštovati raznolikost ... a u stvari radi se o brisanju raznolikosti, a ne o njezinom poštivanju. ${ }^{10}$

U multireligijskim društvima, religijski identitet se često zna, osobito u postkonfliktnom razdoblju, doživljavati kao znak razlike. Svjedočimo li tome i u Bosni i Hercegovini danas? Katolik/pravoslavni/musliman je više znak razlike, nego znak vjerske pripadnosti. Je li onda u pravu Harari kad piše da sekularni svijet procjenjuje ljude na osnovu njihovog ponašanja, a ne po tome kakvu odjeću vole da nose ni kakvih se ceremonija pridržavaju (Harari, 2019)?

Religijske i nacionalne identitete ne treba suprotstavljati, ma koliko svatko svoj identitet (religijski i nacionalni) određuje prema Drugom. To određenje prema Drugom treba zasnivati na uvažavanju i poštivanju, a ne na negiranju i nipodaštavanju Drugoga.

Religijski identitet u Bosni i Hercegovini, uglavnom, nasljeđujemo od roditelja. To nam je prvi njihov "dar". Onaj tko se rodio u muslimanskoj obitelji postaje muslimanom, u katoličkoj - katolikom, u pravoslavnoj - pravoslavnim. Naravno, i taj identitet je - kroz život - podložan promjenama. Ali, za razliku od drugih identiteta, religijski i nacionalni identitet su konstantniji. I jedan i drugi omogućuju pojedincu identifikaciju sa socijalnom grupom (konfesijom, nacijom). ${ }^{11}$ Nikolaj Berđajev je pisao da s dvadesetim stoljećem završava napuštanje Boga i počinje vraćanje Bogu. Ostvaruje li se to Berđajeovo predviđanje? Ako je suditi prema rezultatima popisa stanovništva iz 2013. godine, Berđajev je bio u pravu. Vjerska pripadnost prema popisu stanovništva iz 2013. izgledala je ovako: 50,7 \% muslimani; 15,19 \% katolici, 30,75 \% pravoslavni (ukupno preko 96,64 \%). Da li taj porast konfesionalne samoidentifikacije nužno znači i porast religioznosti? Ne. Konfesionalna samoidentifikacija se kod velikog broja ispitanika izjednačava (ili ima značaj) i nacionalne samoidentifikacije. Pokazalo je to i naše istraživanje. U uzorku je bilo 10,4 Hrvata ili 11,2 \% katolika; 50,3 \% Bošnjaka ili 50,3 \% muslimana; 30,7 \% Srba ili 28,5 \% pravoslavnih. Zašto ima više

\footnotetext{
${ }^{10}$ Bilten franjevačke teologije, Sarajevo, br. 1-2, 2017: 58.

${ }^{11} \mathrm{Na}$ lokalnom nivou (župa, džemat, parohija) možemo govoriti o stvarnoj grupi, zajednici. Sve izvan toga možemo nazvati "zamišljenom" katoličkom, muslimanskom, pravoslavnom zajednicom.
} 
katolika nego Hrvata? ${ }^{12}$ Zato što su se i neki koji su se nacionalno drugačije izjašnjavali samoodredili kao katolici (1 Albanac, 1 bosanski Hrvat, 1 Brazilac, 1 Poljakinja ...). Dakle, 94,2 \% onih koji su se izjasnili kao Hrvati izjašnjavaju se i kao katolici (3,8 \% "nisam vjernik"); Srbi u 90,2 \% slučajeva kao pravoslavni (6,5 \% “nisam vjernik"); Bošnjaci u 94,8 \% kao muslimani (2,4 \% “nisam vjernik"). U kontrolnoj grupi bilo je 18 katolika (studenti Bogoslovnog fakulteta i Franjevačke teologije), 10 muslimana (studenti Fakulteta islamskih nauka) i 9 pravoslavnih studenata Bogoslovije u Foči.

Koje su karakteristike studenata katolika obuhvaćenih istraživanjem? Među studentima društvenih nauka nalazimo više katolika (12,2 \%) i Hrvata $(11,11 \%)$, nego onima koji studiraju tehničke znanosti (2,0 \% i 4,1\%). Katolici prihvaćaju svoju nacionalnu pripadnost, ali ne razmišljaju puno o njoj - 42,9 \% (muslimani 43,8 \%, pravoslavni 35,2 \%, "nisam vjernik" 25,0 $\%$ ); nacionalna pripadnost im je važan dio života - 53,6 \% (muslimani 42,2 \%, pravoslavni 6,3\%, "nisam vjernik" 21,9\%), 91,1\% katolika svoj materinji jezik naziva hrvatskim $(90,4 \%$ muslimana bosanskim i 91,5\% pravoslavnih srpskim).

Mario Vargas Ljosa današnje vrijeme naziva "nevjerničkim". ${ }^{13}$ Pri tom se obično misli na podatke o posjeti crkvi. I tu zaista ima onih koji "imaju Boga samo za nedjelju”, kako zapisa rimsko-njemački car Fridrich II. u XIII stoljeću (Stern, 1993: 222). ${ }^{14}$ Za njih bismo rekli da su "nedjeljni vjernici”, i da slijede "nedjeljno kršćanstvo" - vjernikom i kršćaninom se osjećaju samo nedjeljom kad odlaze na misu/bogosluženje.

Može li se religioznost mjeriti odlaskom u crkvu? "Imam i teškoća da razumem kako se to 'religija' meri putem odlaženja u crkvu”, piše Gil Anidjar (Anižar, 2014: 29). Kao da njegovo mišljenje dijeli i fra Drago Bojić: “... kao što se osobna vjera ne mjeri brojem izgovorenih molitava, brojem odlazaka u crkve i džamije, odlascima na hodočašća i hadž. Vjera nije statistička kategorija niti se Boga može ucijeniti brojkama ..." (Bojić, 2016: 221). Ako vjera i nije statistička kategorija, religija jeste. Brojke pričaju svoju priču koja pokazuje da je odlazak u crkvu u Hrvatskoj (2012.) bio: vrlo često 12,7\%

\footnotetext{
${ }^{12}$ Zašto u uzorku nije bilo više katolika (u društvu ih, prema popisu iz 2013. godine, ima 15,19 \%, a u uzorku 11,2 \%) objašnjenje je dano u tekstu Belinde Kikić.

${ }^{13}$ V. Mario Varagas Ljosa. Pesma nad pesmama. Nedeljnik. Beograd, 18. 4. 2019: 11.

${ }^{14}$ Imamo slučajeva "poistovjećivanja pojmova nominalnog pripadnika jedne veroispovesti i stvarnog, aktivnog vernika. Onaj prvi je samo po rođenju upisan kao pravoslavac, pa se po tradiciji i navici tako iskazuje, dok je po ličnom opredeljenju možda ateist, agnostik ili naprosto nezainteresiran. Onaj drugi, pak, prihvata crkvenu dogmu, vjeruje u Boga, redovno dolazi u crkvu da mu se pomoli, zove sveštenike u kuću u svakoj pogodnoj prilici, i slično ... Razlika između jednog i drugog očito je velika.” (Bugarski, 2005: 113)
} 
(u kafić 10,5\%); gotovo redovito 17,3\% (u kafić 11,1\%); i da i ne 17,1\% (u kafić 16,1\%); vrlo rijetko 18,0\% (u kafić 15,5\%); gotovo nikad 34,8\% (u kafić 47,1\%). ${ }^{15}$ U nekim krajevima Dalmacije i Hercegovine, muškarci kažu "idem kod crkve", a žene "idem u crkvu”. Žene su pobožnije, odlaze "u crkvu" moliti se, a muškarci "kod crkve" kako bi ćaskali o ratarskim i drugim temama, dakako i "o politici".

Naravno da "učestalost odlazaka u crkvu nije pouzdan kriterij za religioznost. Ona može da stoji u korelaciji samo s navikom i običajem, na nekim mestima odlaskom u crkvu iskazuje se čak i jedna manje ili više suptilna prisila grupe", piše Otfried Höffe (Hefe, 2016: 101). Odlaskom u crkvu nećete postati kršćaninom, niti odlaskom u džamiju muslimanom, kao što nećete stojeći u garaži postati automobil. Broj ljudi koji redovito idu na Facebook stotinama puta je veći od ljudi koji redovito idu u crkvu.

Studenti katolici u 7,1 \% slučajeva najmanje jednom tjedno pohađaju crkvu, više puta mjesečno $23,2 \%$, jedanput mjesečno $10,7 \%$ i samo za Božić, Uskrs 3,6 \% (To su tzv. dvodnevni katolici: odlaze u crkvu dva puta godišnje za Božić i Uskrs. Za njih je katoličanstvo "blagdanska pojava".) i jednom godišnje 1,8 \%. Po ovom kriteriju studenti katolici daleko više drže do ovog oblika religijske prakse u odnosu na svoje kolege/ice pravoslavne/ ke ili studente muslimane kad je riječ o odlasku u džamiju. Spolna pripadnost pokazuje da 28,3\% studenata jednom tjedno posjećuje crkvu (studentice 13,4 \%), "više puta mjesečno" 22,0 \% (studentice 14,9 \%), "jedanput mjesečno" 6,3 \% (studentice 13,4 \%). Dakle studenti češće posjećuju crkvu od studentica. Također, studenti tehničkih fakulteta češće odlaze u crkvu u odnosu na studente društvenih nauka. Studenti teologija u 92,1 \% slučajeva u hram odlaze najmanje jednom tjedno ili više puta mjesečno, što je bilo i za očekivati.

Ima osoba koje uživaju u tome da budu viđeni kao posjetitelji crkve/ džamije, pa u istraživanjima izjavljuju da ih posjećuju češće nego što to zaista čine. Ali, da neki odlaze u hramove radi društvenog statusa smatra 89,3\% studenata katolika (da, velik broj 66,1 \% + da, mali broj ljudi 23,2\%).

Svaka religija našeg okruženja ima svoj pisani religijski autoritet. Za kršćane, pa i katolike, to je Biblija. ${ }^{16}$ Različit je odnos prema pisanom religijskom autoritetu. "Kršćani vjeruju u Isusovu božanstvenost, ali isto tako tvrde

\footnotetext{
${ }^{15}$ Izvor: "Jutarnji list", Zagreb, 24. 12. 2012: 4.

16 "Važno je naglasiti da tri velike monoteističke religije nepravilno nazivamo 'religijama Knjige', budući da su budizam, brahmanizam i konfucijanizam takođe religije koje se pozivaju na knjige.” (Eco, 2011: 104)
} 
da su Bibliju napisali ljudi. Židovi vjeruju u svetost Tore koju ljube i prema njoj tijekom bogosluženja postupaju s najvećim poštovanjem, ali se njezino autorstvo tradicionalno pripisuje Mojsiju, Proroku koji je, kao uostalom i svi ostali židovski proroci, tek ljudsko biće i kao takav pogrešiv. Muslimani, međutim, vjeruju ne samo u Muhamedovo nadljudsko savršenstvo već i u svetost Kurana kao riječi izravno primljene od Boga.” (Ali, 2016: 85) Bibliju ili samo Novi zavjet posjeduje 89,3\% studenata katolika; neku drugu "svetu knjigu" 3,6 \%, nijednu "svetu knjigu" 3,6 \%.

Jedno je posjedovati Bibliju u svom domu, a drugo je čitati ju. Studenti katolici izjavljuju da su čitali Bibliju (80,4 \%). Koliko često: svaki dan 16,1 $\%$; nekoliko puta tjedno $12,5 \%$; ponekad 23,2 \%; veoma rijetko 23,2 \%.

Biblija, pisani izvor židovstva i kršćanstva, sastoji se iz dva dijela. Prvi dio (Stari zavjet) obuhvaća razdoblje prije Krista i sastoji se od četrdeset i šest knjiga. Novi zavjet tretira razdoblje poslije Krista i sastoji se od četiri evanđelja, Djela apostolskih, dvadeset i četiri poslanice i Otkrivenja Ivanovog. ${ }^{17}$ Riječ je o jednoj od najčitanijih i najviše prevođenih knjiga. Hebrejske biblijske tekstove (Tora, djela proroka i drugo) kršćani nazivaju Stari zavjet, a židovi Tanah.

Zanimalo nas je znaju li studenti kako se zovu dva dijela od kojih se sastoji Biblija. Studenti katolici znaju $100 \%$ navesti dva dijela od kojih se sastoji Biblija (muslimani 35,5\%, pravoslavni 82,4 \%, nisu vjernici 71,9\%).

Kao sociološke indikatore religioznosti ne uzimamo samo odlazak u crkvu, već i druge pokazatelje, osobito one koji se odnose na duhovnost. Neki ne prave razliku između religioznosti i duhovnosti. Drugi povlače jasnu crtu razgraničenja između religije, religioznosti i duhovnosti. Duhovnost je, za njih, vjerovanje u ideje religijskog značenja (Bog, duša, raj, pakao, i sl.), ali pri tom se ne mora gotovo nikakav značaj pridavati organizacijskoj strukturi bilo koje organizirane religije. U načelu, oni odbacuju religijski organizirane zajednice.

"Geslo našeg doba moglo bi glasiti: Religija - da; Bog - ne" (Metz, 2011: 68). ${ }^{18}$ Albert Einstein je 3. siječnja 1954. godine pisao filozofu Ericu Gutkindu:

\footnotetext{
17 "Dvadeset i sedam knjiga Novog zavjeta, korpus dovršen sredinom drugog stoljeća ... Pisci četiriju evanđelja koja su kasnije pripisana Mateju, Marku, Luki i Ivanu bili su židovski kršćani koji su pisali na grčkom ... Evanđelje po Marku napisano je oko 70. godine, po Mateju i Luki tijekom osamdesetih, po Ivanu krajem devedesetih", piše Karen Armstrong (2012: 94).

18 "Slično tome, hiljadama godina ljudi su se služili Bogom da bi objasnili prirodne pojave. Šta uzrokuje sevanje munja? Bog. Šta prosipa kišu s neba? Bog. Kako je nastao život na Zemlji? Bog ga je stvorio. U prethodnih nekoliko vekova naučnici nisu pronašli nikakav empirijski dokaz o postojanju Boga, ali su našli mnogo podrobnija objašnjenja za munje, kišu i nastanak života. Shodno tome, uz izuzetak nekoliko podogranaka filozofije, nijedan članak u recenziranim naučnim časopisima ne uzima za oz-
} 
Riječ bog za mene nije ništa drugo doli izraz ili proizvod ljudske slabosti, Biblija je zbirka plemenitih, ali i dalje primitivnih legendi koje su ipak prilično djetinjaste. "Albert Einstein je govoreći o religiji budućnosti predviđao da će to biti 'kozmička religija' koja će nadići osobnog Boga i izbjegavati dogmu i teologiju: 'ono nedokučivo namu uistinu postoji. Iza tajni prirode skriva se nešto tanko čudno, neopipljivo i neobjašnjivo. Štovanje te sile koja nadilazi sve nama razumljivo moja je religija' - zaključio je Einstein." 19

U Boga vjeruje 71\% Europljana, pokazalo je istraživanje provedeno u 14 zemalja. Najviše je vjernika u Poljskoj (97\%), Rusiji (87\%), Austriji (84\%), Španjolskoj (80\%). Posljednja je Češka sa 37\%. U život nakon smrti vjeruje $53 \%$ Europljana. ${ }^{20}$ I $86 \%$ hrvatskih građana vjeruje u postojanje Boga; 1/4 Hrvata ide u crkvu jednom tjedno, $43 \%$ jednom mjesečno, $32 \%$ rijetko ili nikad. ${ }^{21}$

Bez Boga se lakše živi, s Bogom se lakše umire. "Jer, bol prethodi svemu. Prvenstveno bogu", pisao je rumunjski književnik Emil Cioran (Sioran, 2011: 121). Nije jednom kazano da dok ima patnje, 'ima' i Boga, nastavlja Cioran (Sioran, 2011: 131). "Neki kineski mislioci i vođe poigravaju se idejama o povratku konfučijanstvu, ali to je uglavnom samo zgodna fasada ... Više od jednog veka pošto ga je Niče proglasio za pokojnog, Bog se izgleda vraća. Samo što je to puka fatamorgana. Bog jeste mrtav, jedino je potrebno vremena da se oslobodimo leša." (Harari, 2018a: 332). "Boga evropske kršćanske tradicije zaista su ubili teolozi, filozofi idealisti i religiozne institucije ... ovu apstraktnu intelektualnu utvaru od Boga koristile su religijske institucije kao strašilo za plašenje i potlačivanje masa religioznoj ideologiji dominantnoj u srednjem veku." (Janos, 2014: 18) ${ }^{22}$

Pojam Boga kojeg susrećemo u zapadnim religijama ne poznaju religije dalekog istoka. Sv. Franjo Ksaverski, stigavši u Japan 1550. prevodio je riječ "Bog" s "Dainči" sve dok nije doznao da to ime označava Budu. Nakon toga je koristio termin Deus, ali je to izazivalo smijeh među slušateljima jer ta riječ

biljno postojanje Boga ... Ista sudbina je zadesila i dušu. Ljudi su hiljadama godina verovali da svi naši postupci i odluke potiču iz duše. U odsustvu bilo kakvih dokaza koji bi ovo verovanje potvrdili, biolozi su odbacili dušu. Kao privatna lica mnogi biolozi i lekari možda i dalje veruju u nju, ali nikada neće o njoj pisati u nekom ozbiljnom naučnom časopisu." (Harari, 2018a: 147-148)

${ }^{19} \mathrm{~J}$.L. O bratskom loncu, u knjizi Velike lože hrvatske ISIS - bez bilo kakvih podataka o izdanju.

${ }^{20} \mathrm{v}$. U Boga vjeruje 71 posto Europljana, “Jutarnji list”, 21. 2. 2005.

${ }^{21}$ Istraživanje američkog Pew Research Centera pod nazivom "Religious Belief and National Belonging in Central and Eastern Europa", objavljeno 2017.

${ }^{22}$ Ovdj, na Balkanu, ni Bog nije isti: židovi imaju svog Boga, muslimani svog (zovu ga Allah), katolici svog (zovu ga Krist), pravoslavni svog (zovu ga Hrist). Doživljavaju li ga studenti kao jednog boga u četiri varijante, ili četiri zasebna boga? 
na japanskom znači "debela laža”. Kasnije su Japanci koristili riječ "Tenču” Gospodar neba, a od 1989. godine u prijevodu Biblije su riječ "Bog” preveli s riječju "Kami” (Chouragui, 2005: 214). "Bog postoji jer se ne može dokazati da ne postoji. Bog ne postoji jer se ne može dokazati da postoji. Bog je - igra riječima”, kako zapisa rimsko-njemački car Fridrich II. u XIII stoljeću (Stern, 1993: 26)..$^{23}$

Istraživanja pokazuju da ima ljudi koji vjeruju u Boga, ali gotovo da nemaju nikakvo religiozno ponašanje. S druge strane postoje oni što imaju religijsko ponašanje, a nemaju vjere u Boga (budisti, ali i ne samo oni). ${ }^{24}$ U postojanje Boga vjeruje 98,2 \% studenata katolika (i 98,1 \% studenata Hrvata). Zanimljivo da 2,6 \% studenata teologije nije sigurno u postojanje Boga. Studentice nešto više vjeruju u postojanje Boga (90,4\%) u odnosu na studente $(83,6 \%)$. Što se tiče vjerovanja u postojanje Boga, tu su gotovo izjednačeni studenti društvenih $(89,6 \%)$ i tehničkih nauka $(87,8 \%)$.

U postojanje duše vjeruje 94,6 \% studenata katolika (i 90,4 \% studenata Hrvata). U postojanje duše više vjeruju studentice (82,0 \%), nego studenti (74,2 \%), više vjeruju studenti društvenog usmjerenja (80,2 \%) za razliku od studenata tehničkih fakulteta $(69,4 \%)$. Tek 2,6 \% studenata teologije ne vjeruje u postojanje duše.

Vjera u zagrobni život postoji i u kršćanstvu i islamu, religijama kojima pripada 90,0 \% ispitanika. ${ }^{25} \mathrm{U}$ postojanje zagrobnog života vjeruje $82,1 \%$ studenata katolika (i 76,9 \% studenata Hrvata). U postojanje zagrobnog života vjeruje 58,2 \% studenata društvenog usmjerenja i 44,9 \% studenata tehničkog usmjerenja. I ovdje se pojavljuje podatak da 2,6\% studenata teologije ne vjeruje u zagrobni život.

Raj je koncept života poslije smrti kojega zagovaraju gotovo sve religije. U postojanje raja vjeruje 94,6 \% studenata katolika (i 92,3\% studenata Hrvata). Studentice više vjeruju u postojanje raja/dženeta $(70,9 \%)$ u odnosu na studente $(66,7 \%) ; 73,6 \%$ studenata društvenog usmjerenja vjeruje u postojanje raja/dženeta i 57,1\% studenata tehničkog usmjerenja. Zanimljivo, papa Franjo je u pismu koje je uputio La Republica dnevnim novinama (2015), poručio da ateisti ne moraju vjerovati u Boga da bi otišli u raj.

\footnotetext{
23 "Volter je rekao: Bog ne postoji, ali nemojte to da kažete mom slugi da me ne bi ubio na spavanju." (Harari, 2019a: 153)

24 “Središnji lik budizma nije bog nego ljudsko biće, Sidarta Gautama." (Harari, 2019: 292)

25 "Do XVIII veka religije su smrt i zagrobni život smatrale okosnicom životnog smisla. Počinjući od XVIII veka religije su ... izgubile svako zanimanje za zagrobni život.” (Harari, 2019a: 351).
} 
U postojanje Vraga/Sotone vjeruje 80,4 \% studenata katolika (i 76,9 \% studenata Hrvata). Među studentima teologije 5,3\% ih je koji ne vjeruju u postojanje vraga/sotone/šejtana. ${ }^{26}$

U postojanje pakla/džehenema vjeruje $85,7 \%$ studenata katolika (i 82,7 \% studenata Hrvata). Nije sigurno u postojanje pakla/džehenema 5,3 \% studenata teologije.

U postojanje uskrsnuća vjeruje 87,5\% studenata katolika (i 86,5 \% studenata Hrvata). Među studentima teologije 5,3 \% je onih koji ne vjeruju u uskrsnuće.

U postojanje grijeha vjeruje 92,9\% studenata katolika (i 90,4 \% studenata Hrvata). I u postojanje grijeha više vjeruju studentice $(80,0 \%)$ u odnosu na studente $(72,3 \%)$.

Ispitanici najmanje vjeruju u uskrsnuće $\operatorname{mrtvih}^{27}$, potom zagrobni život, vraga/sotonu/šejtana itd. Prema gore navedenim indikatorima, studentice su nešto religioznije od studenata. Ali, studenti su nešto informiraniji o strukturi religijskih zajednica i religijskim vodstvima u njima.

Onaj tko zna jedno, ne zna ni jedno, rekao bi Goethe. Ili, onaj tko poznaje samo jednu religiju (u pravilu "svoju") ne poznaje nijednu. Pored ostalog i zato smo studente pitali koji grad ima izuzetnu važnost i za kršćane i za muslimane i za židove?

Jeruzalem ima posebno važno mjesto u predaji triju monoteističkih religija: židovstvu, kršćanstvu i islamu, što je kroz povijest izazivalo brojne sukobe. To je "sveti grad" za pripadnike navedenih religija. Još za vrijeme cara Davida postao je religijsko središte židovske religije u kojem je čuvan Zavjetni kovčeg (Božji). U njemu se nalazi nekoliko važnih vjerskih znamenitosti kao što su: Brdo hrama i Zid plača (koji su sveti židovima), Bazilika Svetoga groba (sveta kršćanima), te Kupola na stijeni i džamija al-Aksa (sveti muslimanima).

Studenti katolici su dobro informirani da je riječ o Jeruzalemu: točan odgovor znalo ih je 92,9 \% (daleko više i od studenata muslimana - 61,8 \% i od studenata pravoslavaca - 77,5\%). O tome su informiraniji studenti društvenih nauka (74,0 \% ih je znalo točan odgovor, u odnosu na 55,1 \% studenata tehničkih nauka).

\footnotetext{
26 "Ljudi imaju čudesnu sposobnost da gaje protivrečna verovanja. Zato ne bi trebalo da nas iznenađuje što milioni pobožnih hrišćana, muslimana i Jevreja uspevaju istovremeno da veruju i u svemogućeg Boga i u nezavisnog Đavla." (Harari 2019a: 290)

${ }^{27}$ Godine 2006., 80 \% Talijana sebe je smatralo katolicima, a 30 \% je nazočno na nedjeljnoj misi (U Francuskoj $10 \%$ ); $40 \%$ ih nije vjerovalo u uskrsnuće (a to je temelj kršćanske vjere).
} 
Deset zapovijedi ili Dekalog čine temelj židovske i kršćanske vjere. Provjerili smo kod studenata znaju li ih navesti. Pokazalo se da 57,14 \% studenata katolika zna navesti Deset zapovijedi (niti jedan musliman, 33,8 $\%$ pravoslavnih). Zanimljivo da je tek svaki drugi student teologije (50,0 \%) znao točno navesti svih Deset zapovijedi (što znači da ih ne znaju navesti ni svi studenti katoličke i pravoslavne teologije).

Evanđelja (evanđelje - radosna vijest) su važan pisani izvor za katolike (i kršćane uopće). ${ }^{28}$ Čine ih prve četiri knjige Novog zavjeta ${ }^{29}$ koje govore o zemaljskom Isusovom životu. ${ }^{30}$ Od trideset evanđelja, u kanonu su priznata četiri: Matejevo, Markovo, Lukino i Ivanovo/Jovanovo.

Da su Matej, Marko, Luka i Ivan/Jovan pisci četiriju evanđelja znalo je 94,6 \% studenata katolika (24,7 \% muslimana, 56,3\% pravoslavnih); 44,2 \% studenata društvenog usmjerenja i 32,7 \% studenata tehničkog usmjerenja, te $86,8 \%$ studenata teologije.

I u odgovoru na ovo pitanje uočljiva je znatno veća informiranost studenata katolika o kršćanstvu, u odnosu na studente pravoslavne.

Važan dio kršćanske religije, kamo spada i katoličanstvo, jeste sedam sakramenata/svetih tajni. Sakrament je kršćanski obred za koji vjernici vjeruju da vodi spasenju. Katolici i pravoslavni priznaju sedam sakramenata (krštenje, potvrda ili krizma, pričest, ispovijed, bolesničko pomazanje, svećeničko ređenje, ženidba), a protestanti samo dva: krštenje i pričest.

Studentima smo u tabeli ponudili deset obrednih aktivnosti od kojih tri ne spadaju u sakramente/svete tajen. Trebali su među odgovorima pronaći ta "tri uljeza". Da su to obrezanje znaju 100\% studenti katolici (78,2 \% pravoslavni); misa/liturgija - 67,9\% studenata katolika i tek 16,9\% studenata pravoslavnih. Tek svaki drugi student teologije $(50,0 \%)$ zna da misa/liturgija ne spada među sedam svetih sakramenata. Na kraju da tu ne spada ni pomazanje znalo je $66,1 \%$ studenata katolika (27,5 \% pravoslavnih). Iznenađuje da samo 57,9 $\%$ studenata teologije zna da pomazanje ne spada u sedam svetih sakrame-

\footnotetext{
28 "Evanđelje nije religija, već samo materijal za njezino stvaranje. Koliko ljudi - toliko religija”, kako piše Ljudmila Ulicka u romanu Jakovljeve ljestve (2018: 257).

29 "Nitko ne zna tko su bila četiri evangelista, ali je gotovo sigurno da oni nikad nisu susreli Isusa osobno" (Dawkins, 2007: 93).

30 “... povodom pisaca jevanđelja. Možda je Isus pričao nešto sasvim drugo od onoga što su nam oni prenijeli? (Eco) Po svemu sudeći i jeste. Često zaboravljamo da su najstariji hrišćanski tekstovi koje posjedujemo Poslanice Pavlove. Jevanđelja su nastala kasnije. A ličnost Pavla, prvog izumitelja hrišćanstva, izuzetno je složena... Pavle je bio taj koji će hrišćanstvo definitivno odvojiti od judaizma, i koji će prvi početi da se obraća 'neznabošcima', odnosno, ne-Jevrejima. On je utemeljitelj vjere." (Karijer, 2011: 111)
} 
nata. I kod ovog pitanja uočljive su velike razlike među studentima kršćanima (katolicima i pravoslavnima) o poznavanju ovog elementa svoje religije.

Veliki raskol u kršćanstvu nastao je 1054. godine kada se Rimska crkva proglasila katoličkom (grčki katholu - sveopći), a Carigradska i one koje su je podržale (Aleksandrijska, Antiohijska, Jeruzalemska) ortodoksnom (grčki orto doxa - pravovjerni). Od tada traju međusobna optuživanja za herezu, što je stvaralo (i još uvijek stvara) napetosti među katolicima i pravoslavnima. ${ }^{31}$ Pitali smo studente: Da li vam je poznato koje godine se kršćanstvo podijelilo na zapadno (katoličko) i istočno (pravoslavno)? Točan odgovor znalo je $75,0 \%$ studenata katolika (i 78,2 \% pravoslavnih). Ovo je jedno od rijetkih pitanja o kojem su studenti pravoslavni iskazali veću informiranost u odnosu na studente katolike $(+3,2 \%)$.

Među svećenstvom Katoličke Crkve u Bosni i Hercegovini djeluje nekoliko redovničkih zajednica. Od njih franjevci u Bosni i Hercegovini imaju najdužu tradiciju: tu su od trinaestog stoljeća. Svakako da su, kada je riječ o Bosni i Hercegovini, najpoznatija katolička redovnička zajednica. Tako smo pretpostavljali. Na opće iznenađenje, to zna samo 14,83 \% ispitanika (Bilo je i ovdje čudnih odgovora: biskupija, HDZ, katedrala...). Čak se ni studenti katolici ne mogu pohvaliti znanjem o franjevačkoj zajednici. Da je to najpoznatija od katoličkih redovničkih zajednica u Bosni i Hercegovini, znalo je 59,0 \% studenata katolika. Točan odgovor znalo je 15,8 \% studenata društvenih nauka i 4,1 \% studenata tehničkog usmjerenja, te 52,5\% studenata teologije (podsjećamo da je u kontrolnoj grupi bilo 48,6 \% studenata katoličkih teologija).

U Bosni i Hercegovini ima više samostana u kojima franjevci čuvaju ogromno kulturno blago (knjižnice, muzeji, umjetničke galerije...). Često se o tome piše i u medijima. Provjerili smo među studentima znaju li tko upravlja samostanom. Da samostanom upravlja gvardijan znalo je tek 18,6 \% ispitanika. ${ }^{32}$ Nešto više je to poznato studentima katolicima: $57,1 \%$ ih je znalo točan odgovor. Točan odgovor dalo je 19,8 \% studenata društvenih i 8,2 $\%$ studenata tehničkih nauka, te $71,1 \%$ studenata teologije.

Zanimalo nas je znaju li ispitanici kojim se međusobnim pozdravom pozdravljaju pripadnici religijskih zajednica u Bosni i Hercegovini. Da je “Hvaljen Isus i Marija” pozdrav među katolicima, znalo je 81,4 \% studenata.

\footnotetext{
31 "Religija, umesto da zbližava ljude, postala je činilac razlaza: hrišćanstvo se podelilo na suprotstavljene konfesije koje jedna drugoj ljubomorno spore pravo da su autentični izraz hrišćanske istine." (Remond, 2017: 29)

${ }^{32}$ Najviše ih je (55,3 \%) odabralo odgovor "Ne znam", 7,4 \% upravlja provincijom, a 6,4 \% župom.
} 
Najviše studenti katolici: njih 96,4 \%. To je znalo 84,0 \% studenata društvenih i 57,1\% studenata tehničkih nauka, te 94,7\% studenata teologije.

Koliko studenti katolici poznaju nazive religijskih vođa u Katoličkoj Crkvi? Da je župnik religijski vođa u katoličkoj crkvi zna 85,7 \% studenata katolika, da tu spada biskup zna ih $82,1 \%$. To je poznato i za $84,2 \%$ studenata teologije. Da je papa religijski vođa u Katoličkoj crkvi zna 89,3\% studenata katolika i 81,6\% studenata teologije.

\section{Poznavanje religije svojih susjeda}

\section{a) Poznavanje židovske religije}

Rekli smo da je Talmud pisani religijski izvor u židovskoj religiji. Da li studenti katolici u svom domu imaju taj izvor učenja svojih susjeda židova? Tek ih 7,1 \% izjavljuje da posjeduju Talmud. Znatno više ih izjavljuje da su ga čitali - $54 \%$. Nismo imali kontrolna pitanja kojima bismo to provjerili. ${ }^{33}$

Bilo bi za očekivati da polaznike vjeronauke poučavaju o osnovnim pitanjima iz povijesti židovske religije u Bosni i Hercegovini. Pitali smo studente, a gotovo su svi pohađali vjeronauku, da li znaju iz koje zemlje su u Bosnu i Hercegovinu, stigli Sefardi (židovi) nakon progona? Prisjetimo se da se veliki progon židova iz Španjolske dogodio 1492. godine. Dio ih je našao utočište u Grčkoj. Tako su, nakon 1493. godine, iz Soluna (nešto i preko Dubrovnika) došli u Sarajevo gdje su se nastanili u zasebnoj četvrti. Sefard je židovski izraz za Iberijski poluotok i po njemu su židovi iz Španjolske dobili naziv. Njeguju "ladino" jezik - jezik španjolskih, sefardskih židova. Da su židovi u Bosnu i Hercegovinu došli iz Španjolske znalo je tek 26,8 \% studenata katolika (i 63,2 \% studenata teologije).

Prema židovskom nauku, Bog se ukazao Mojsiju na gori Sinaj i priopćio mu Deset zapovijedi. Riječ je o religijsko-moralnim zapovijedima koje iskazuju etičke i socijalne zabrane (nisu li one temeljni dio i kršćanskog morala?). Taj podatak znalo je 87,5\% studenata katolika.

Pripovjedački elementi Talmuda (molitve i obredi) koji se čitaju prve dvije večeri Pesaha sadržani su u Haggadi. Haggadah na židovskom znači obznaniti ili pričati priču. Po bogatoj ilustraciji ističe se Sarajevska Haggadah iz XIV. stoljeća, napisana u Španjolskoj. Nastala je negdje u sjevernoj Španjolskoj, u drugoj polovici 14. stoljeća, dakle poslije 1350. godine. Da

\footnotetext{
${ }^{33}$ Mada u odgovoru na pitanje "Posjedujete li neku od 'svetih knjiga' u svom domu, samo je 3,6 \% studenata katolika odgovorilo da posjeduje "neku drugu svetu knjigu".
} 
se židovi za blagdana Pesah služe Haggadom znalo je tek 21,4 \% studenata katolika.

Ašto je Pesah? Toje obiteljski blagdan. Svetkuje se noću, o uštapu proljetne ravnodnevice, 14. dana mjeseca abiba. Tim blagdanom evocira se prelazak židova iz egipatskog ropstva u obećanu zemlju Kanaan pod Mojsijevim vodstvom. Tim povodom jedu se tradicionalna jela, pjevaju pjesme i pripovijeda o izbavljenju iz Egipta. Pesah je jedan od tri hodočasna praznika kada svi židovi koji imaju mogućnost, hodočaste u Jeruzalem. Provjerili smo koliko studenti znaju da je Pesah židovski blagdan u čast izlaska iz egipatskog ropstva. To je znalo 75,0 \% studenata katolika; 30,4 \% studenata društvenih nauka za razliku od 10,2 \% studenata tehničkih nauka, te $86,8 \%$ studenata teologije.

Židovima na sabat (subotu), koji počinje u petak nakon "zalaska" Sunca i traje do subote nakon "zalaska" Sunca, nije dopušteno paljenje vatre, upotreba novca, telefoniranje, vožnja automobilom, kuhanje, paljenje svijetla, itd. Da im nije dozvoljeno paliti svjetlo zna 7,1 \% studenata katolika; spremati hranu 19,6 $\%$; zabranjeno voziti automobil $12,5 \%$; da ne smiju koristiti telefon $12,5 \%$.

Da u religijskim tradicijama na području Bosne i Hercegovine obred obrezanja $^{34}$ (pored muslimana) prakticiraju i židovi znalo je 44,7 \% ispitanika. Iznenađujuće je da tako mali broj ispitanika zna da je obrezanje obveza u židovskoj religiji, kao i to da 5,6\% ispitanika smatra da je to obredna praksa katolika i 2,8 \% pravoslavnih. Da taj obred prakticiraju i židovi znalo je 76,8 \% studenata katolika (Točan odgovor znalo je 89,5 \% studenata teologije).

Da se pripadnici židovske religije za bogosluženje okupljaju u hramu koji se zove sinagoga zna tek 51,90 \% ispitanika. Među upisanim odgovorima bilo je i "bisera" da je to "Đurđevdan", "Katedrala", "Tora", "Zid plača". Da je sinagoga židovski hram zna 64,3\% studenata katolika; 54,5 \% studenata društvenih nauka; 28,6 \% studenata tehničkih, te 76,4 \% studenata teologije.

Još je porazniji podatak da samo $34,47 \%$ ispitanika zna da je Davidov znak (šestokraka zvijezda) simbol židovske religije. I ovdje je, među slobodnim odgovorima, bilo "bisera" koje valja zabilježiti: "Apokrif”, "Buda”, "križ”, "menora", "petokraka", "svastika", itd. Da je Davidov znak simbol židovske religije zna 48,3\% studenata katolika (71,0 \% studenata teologije).

Da se pripadnici židovske religije međusobno pozdravljaju sa "Šalom" zna 89,3\% studenta katolika. Također, 78,6 \% ih zna da je rabin naziv religijskog vođe u židovskoj religiji.

\footnotetext{
34 “Klasični izvori slažu se u tome da se obrezivanje prvo pojavilo kod Egipćana i Etiopljana te se otuda proširilo u druge dijelove Bliskog istoka sve do Kolhide na Crnom moru." (Assmann, 2010: 255)
} 
Stari sporovi između kršćana i židova kao da su potisnuti, osobito, kad je riječ o rimokatolicima, nakon II vatikanskog koncila. Kao da su prevaziđene negativne percepcije kršćana o židovima (i obratno). Od polemika prešlo se na dijalog (odustalo se od interpretacija o židovskoj krivnji za Isusovo raspeće). ${ }^{35}$

Zamolili smo ispitanike da naznače koje osobine - od navedenih 24 - odlikuju pripadnike različit religijskih zajednica u Bosni i Hercegovini. Navodimo deset karakteristika za pripadnike židovske konfesije koje su najčešće navodili studenti katolici: ispitanici ih doživljavaju kao vrijedne (16,1\%), škrtim $(14,3 \%)$, nepristupačnim $(10,7 \%)$, inteligentnim $(8,9 \%)$, snalažljivim $(8,9$ $\%)$, konzervativnim $(8,9 \%)$, prevrtljivim $(7,1 \%)$, tolerantnim $(7,1 \%)$, privrženim obitelji $(5,4 \%)$, impulzivnim $(5,4 \%)$.

Također 58,9 \% ih izjavljuje da ih poštuje, 32,1\% "nemam ništa protiv njih", "ne volim ih" 3,6\%.

Što na kraju reći o poznavanju židovske religije među studentima katolicima? ${ }^{36}$ Ako kao kriterij uzmemo odgovore na pitanja iz koje su zemlje židovi stigli u Bosnu i Hercegovinu, znanje o Haggadi, što je židovima zabranjeno raditi na sabat, koji je simbol židovske religije, kao i izbor osobina o židovima, možemo reći da je to znanje iznenađujuće slabo. ${ }^{37}$ Nešto se bolji dojam dobiva ako promatramo odgovore na pitanja kome je Bog objavio Deset zapovijedi, što židovi obilježavaju na blagdan Pesah, da su zadržali obred obrezanja i kako se međusobno pozdravljaju. No, to samo donekle ublažava prethodnu ocjenu.

\section{b) Poznavanje islama}

U Bosni i Hercegovini, prema popisu stanovništva iz 2013. godine, pripadnici islama, muslimani, čine 50,7 \% njene populacije. U Federaciji čak 71,28 \% stanovništva. A i katolici su, uglavnom, skoncentrirani na području Federacije (22,10\% stanovnika Federacije). Samo 2,35 katolika (od njih $15,19 \%)$ živi u Republici Srpskoj. Ovi podaci upućuju na zaključak da bi studenti katolici trebali poznavati islam i bolje od ostalih religija (konfesija) u Bosni i Hercegovini. Da li je to tako? Slijedimo pokazatelje koji bi nas mogli dovesti do valjanog odgovora.

\footnotetext{
35 “... istinsku vrednost ljudi treba prosuđivati prema njihovom ponašanju, a ne prema religijskoj pripadnosti”, piše Harari (Harari, 2019: 88).

36 "Židovska je religije bliska našoj, isto kao i muslimanska, isti su kamenčići u mozaiku, treba ih samo znati poslagati”, piše Olga Tokarczuk u romanu Knjige Jakubove (2019: 529).

37 “... sumnjiva religija. Zašto sumnjiva? Jer je previše bliska. Iste Knjige, Mojsije, Abraham, Izak na kamenu pod očevim nožem, Noa i njegova Arka, sve isto ..." (Tokarczuk, 2019: 600).
} 
Kur'an je sveta Knjiga za muslimane, osnovni pisani izvor njihovog naučavanja. Onaj tko želi znati osnove o islamu morao bi ponajprije upoznati se s Kur'anom. Istraživanje je pokazalo da tek 17,9 \% studenata katolika izjavljuje kako u kući posjeduju Kur'an (i 47,4 \% studenata teologije izjavljuje da posjeduje Kur'an). Nešto veći postotak (25,0\%) ih izjavljuje da je i čitalo Kur'an. ${ }^{38}$

Kur'an je podijeljen na poglavlja koja se nazivaju sure. Ima ih 114. Njihov redoslijed nije kronološki. Duže su na početku, a kraće na kraju Knjige. Tek svaki treći student $(33,67$ \%) je znao navesti kako se nazivaju poglavlja koja sačinjavaju Kur'an. Ni studenti katolici se ne mogu pohvaliti kako im je to poznato - tek ih je $26,8 \%$ znalo da su to sure.

Je li molitva "temeljni" izraz religijskog osjećanja. Vjernici se, tijekom molitve, licem okreću prema "svetom mjestu" (često mjestu začetka te religije). Molitva može biti jutarnja, podnevna, večernja...; osobna i grupna. Položaj tijela pri molitvi može biti različit: stojeći, klečeći, čučeći, čelom dodirujući zemlju, itd. U početku su u islamu bile obvezatne dvije molitve (ujutro i uvečer). Kasnije je uvedena obveza pet molitvi tijekom dana. Prva jutarnja molitva je sabah, potom podne, ikindija, akšam i jacija - posljednja molitva dva sata nakon "zalaska" Sunca. Da jacija označava jednu od pet dnevnih molitvi muslimana zna ukupno 36,5 \% studenata; $10,0 \%$ studenata katolika. Točan odgovor je znalo 31,6 \% (ili 12) studenata teologije. Ako imamo u vidu da je u kontrolnoj grupi bilo deset studenata Fakulteta islamskih nauka, onda možemo zaključiti da je katastrofalno slabo znanje studenata katoličkih i pravoslavne teologije o pet dnevnih molitvi kod muslimana.

Kad je riječ o religijskim zajednicama u Bosni i Hercegovini treba imati u vidu da je riječ o zamišljenim zajednicama koje okupljaju na stotine stanovnika Bosne i Hercegovine od kojih se gotovo svi međusobno ne poznaju, ali "zamišljaju" da se poznaju. Ma koliko svećenici i sveštenici pokušavali graditi svijest o zajednici, imami o tome kako su svi muslimani braća, ipak riječ je o zamišljenim zajednicama. Svaka religijska zajednica ima svoje vodstvo - najniže, srednjeg i najvišeg ranga. Tako Islamsku zajednicu predvodi reisu-1-ulema. Muftija predvodi vjernike s područja muftiluka. Imam je najniže zvanje u islamskoj zajednici i predvodi vjernike najniže organizacijske jedinice - džemata. Naveli smo u upitniku nazive muftija, imam i reisu-1-ulema i zamolili studente da ih poredaju po rangu kojeg zauzimaju u Islamskoj zajednici. Da je reisu-1-ulema prva ličnost u hijerarhiji Islamske

\footnotetext{
${ }^{38}$ Pogledati napomenu u fusnoti 28.
} 
zajednice zna 53,6 \% studenata katolika; muftija druga zna 51,8 \%; imam treća $48,2 \%$.

Studenti teologija ne mogu se baš mnogo pohvaliti o poznavanju hijerarhije religijskih vođa u Islamskoj zajednici. Da je reisu-l-ulema na prvom mjestu navelo je 71,1 ispitanika, muftija na drugom 78,9\%, a imam na trećem mjestu $68,4 \%$.

Svaka religijska zajednica u Bosni i Hercegovini ima svoj kalendar ${ }^{39}$ : židovi imaju svoj židovski kalendar, katolici gregorijanski, pravoslavni julijanski. Muslimani imaju hidžretski lunarni kalendar, te se blagdani "kreću", "pomjeraju” kroz godišnja doba. Godine su se počele računati od 622 kad je, po islamskoj predaji, Muhamed prešao iz Meke u Medinu. Zanimljivo da je Saudijska Arabija 2016. odbacila lunarni u korist gregorijanskog kalendara koji se koristi u većini zemalja svijeta. Odluku je odobrio kralj Salman zbog bolje poslovne prakse. ${ }^{40}$

Da muslimani svoj kalendar računaju od 622 godine znalo je tek 15,0 $\%$ ispitanika. Studenti katolici su se pokazali nešto informiraniji od ostalih - 26,8 \% ih je znalo taj podatak (Samo je 39,5 \% studenata teologije znalo točan odgovor).

Bajram je veliki vjerski blagdan $\mathrm{u}$ islamu. Tijekom godine postoji Ramazanski bajram (traje tri dana), a slavi se nakon ramazanskog posta $\mathrm{i}$ Kurban-bajram (traje četiri dana) kada se prinosi žrtva - kurban. U Bosni i Hercegovini se tradicionalno obilježavaju oba Bajrama te ne iznenađuje da je $94 \%$ ispitanika znalo točan odgovor na pitanje koja su dva "Najpoznatija praznika/blagdana kod muslimana?" 41 Da su dva najpoznatija blagdana kod muslimana Ramazanski bajram (91,1\% studenata katolika to navodi) i Kurban-bajram (87,5\% studenata katolika to zna).

Svečana skupna podnevna molitva petkom u džamiji naziva se džuma. Ona ne može biti individualna i ne obavlja se izvan džamije. U njoj imam uči hutbu vjerskog ili moralnog karaktera. Svaki slobodan i odrastao muškarac dužan je poći na džumu. Ona je valjana ako su joj nazočne najmanje tri odrasle muške osobe. Koliko je studentima katolicima poznato da njihovi sugrađani muslimani petkom idu na džumu (kao što oni nedjeljom idu na misu)? To je znalo $60,8 \%$ studenata katolika.

\footnotetext{
39 “Uz sjećanje, kalendar je još jedna važna institucija vremena. Kalendar je čovjekovo sidro u vremenu", piše Miljenko Jergović (Jergović, 2015: 41).

${ }^{40}$ v. "Oslobođenje", Sarajevo, 4. 10. 2016: 64.

41 "U Egiptu se Prorokov rođendan slavi kao jedna vrsta islamskog Božića...To je u Egiptu najveći vjerski pučki blagdan. Slično je i u Pakistanu" (Kuschel, 2011: 30).
} 
Obrezanje (u islamu se zove sunet) je jedan od prastarih običaja uvođenja u novo životno doba. U religijskim tradicijama na području Bosne i Hercegovine prakticiraju ga muslimani i židovi. Podatak da je obred obrezanja zadržan kod muslimana znalo je 89,3 \% studenata katolika.

Između više ponuđenih odgovora, ispitanike smo zamolili, da zaokruže pet odgovora koji predstavljaju pet osnovnih načela koje mora poštovati i živjeti svaki musliman. Koliko je to poznato studentima katolicima? Oni znaju da među pet osnovnih načela koje mora poštovati svaki musliman spada šehadet - ispovijedanje vjere $(53,6 \%)$, namaz ili molitva $(73,2 \%)$, post $(67,9 \%)$, zekat $(44,6 \%)$ i hadž $(62,5 \%)$.

Svaka religija, pa i islam, ima svoj simbol. Iznenađenje je da je samo 14,83 $\%$ ispitanika znalo da je polumjesec sa zvijezdom simbol islama (osobito $\mathrm{s}$ obzirom da 50,3\% ispitanika se opredijelilo kao muslimani). Najveći broj ispitanika je odgovorio da je simbol islama mjesec i zvijezda (46,89 \%). Bilo je tu i odgovora poput onih da je simbol islama džamija, Kur'an, monoteizam... Da su polumjesec i zvijezda simbol islama znalo je 32,2 \% studenata katolika; 20,1\% studenata i 13,0 \% studentica znalo je da su polumjesec i zvijezda simbol islama, te $28,9 \%$ studenata teologije (praktično toliko je bilo u kontrolnoj grupi studenata Fakulteta islamskih nauka).

Da je zekat obvezni milodar kod muslimana zna 33,9 \% studenata (Točan odgovor znao je i svaki drugi student teologije - 50,0 \%).

Zanimalo nas je znaju li studenti katolici kojim se međusobnim pozdravom pozdravljaju muslimani. Da je "Es-selamu alejkum" ("Mir i spas vam želim") pozdrav među muslimanima zna 92,9\% studenata katolika.

Na pitanje da navedu nazive religijske zajednice kojoj pripadaju sljedeće religijske vođe, da je reisu-1-ulema religijski vođa u Islamskoj zajednici znalo je 76,8 \% studenata katolika, kao i muftija - 82,1\%.

Navedimo i osobine koje, po mišljenju studenata katolika, odlikuju muslimane?

Od dvadeset i četiri osobine koje smo ponudili u upitniku, studenti katolici su izdvojili sljedećih deset koje, prema njihovom mišljenju, odlikuju muslimane: neobrazovani $(28,6 \%)$, primitivni $(25,0 \%)$, ekstremni nacionalisti (23,2 \%), ratoborni $(23,2 \%)$, konzervativni $(21,4 \%)$, veoma religiozni $(16,1$ $\%)$, prevrtljivi $(16,1 \%)$, naivni $(16,1 \%)$, nepristupačni $(14,3 \%)$, praznovjerni (12,5\%).

A na pitanje da iznesu svoje mišljenje o muslimanima 60,7 \% studenata katolika izjavljuje "poštujem ih" (66,5 \% studenata muslimana njih), "nemam 
ništa protiv njih“ 17,9 \%, "ne volim ih” 21,4 \% (njih ne voli 2,4 \% studenata muslimana). ${ }^{42}$

Otkud ovakvi stavovi studenata katolika prema muslimana? Je li to rezultat ratnih (a i poratnih) događanja na području Hercegovačko-neretvanskog kantona $^{43}$ (Iz tog kantona su najvećim dijelom studenti katolici)? Na to kakvu će pojedinac sliku o Drugom kreirati utječe ne samo razina obrazovanja već $i$ sredina u kojoj živi, iskustvo, kao i političke orijentacije. Ako su ovo vrijednosni sudovi o muslimanima najobrazovanijeg dijela omladine, što se tek krije u srcima onih manje obrazovanih? I tko snosi za to moralnu odgovornost? Roditelji, učitelji, vjeroučitelji, nastavnici, profesori - svi.

S muslimanom mogu biti: drug/arica izjavljuje 67,9 \% studenata katolika; susjed/komšija 55,4 \%; imati ga za šefa 37,5 \%; imati ga kao poslovnog partnera 50,0 \%; kao nastavnika svoje djece 37,5\%; kao kućnog prijatelja $55,4 \%$; a imati ga za zeta/snahu $16,1 \%$.

Što na kraju reći o poznavanju islama među studentima katolicima. Ako pogledamo odgovore o posjedovanju i čitanju Kur`ana; poznavanju naziva poglavlja Kur>ana; nazivu dnevnih molitvi kod muslimana; od koje godine se računa islamski kalendar; poznavanje simbola islama i propisane milostinje možemo reći da je poznavanje islama među studentima katolicima apsolutno nezadovoljavajuće (bez obzira na relativno dobro poznavanje religijskih vođa u Islamskoj zajednici, blagdana koje slave muslimani, džume, obrezanja i muslimanskog pozdrava).

\section{c) Poznavanje pravoslavlja}

Katoličanstvo i pravoslavlje su dva ogranka iste religije - kršćanstva. To znači veliku podudarnost u njihovom naučavanju i etičkim porukama. Isto tako to znači da je poznavanje niza pitanja iz domena kršćanstva zajedničko i za pravoslavne i za katolike (“Oče naš” kao najznačajnija molitva; Uskrs/ Vaskrs i Božić kao glavni blagdani u pravoslavlju i katoličanstvu; križ kao simbol; odlazak nedjeljom na misu/bogosluženje; Biblija kao pisani religijski autoritet; sedam sakramenata/svetih tajni; Deset zapovijedi; tko su

\footnotetext{
${ }^{42}$ Napomena: Trebalo bi uzeti u obzir i frekvencije: 6 muslimana ne voli katolike, a 12 katolika ne voli muslimane. Broj katolika koji su odgovorili na ovo pitanje je 56, a broj muslimana 235. Međutim, ne možemo reći da je broj u postotcima u pola veći, već je ovih 6 ispitanika 21,4 \%, a ovih 12 je 2,4 \% ispitanika.

43 "U povijesti nisu rijetka vremena u kojima se javni prostor pomrači... Oni koji su živjeli u takvim vremenima i koje su ona formirala vjerojatno su uvijek naginjali preziranju, maksimalnom ignoriranju, čak i preskakanju svijeta i javnosti i posezanju, takoreći, iza njih ... kako bi se uzajamno razumjeli sa svojim bližnjima ne obazirući se na svijet između njih." (Arendt, 2019: 19)
} 
autori evanđelja; kada je nastao raskol na istočno i zapadno kršćanstvo...). O njihovom poznavanju među studentima katolicima već smo pisali. Ipak postoje i neke razlike među katolicima i pravoslavnima: u kalendaru vjerskih blagdana; načinu života, nazivima i odijevanju religijskih vođa i sl.

Provjerili smo koliko studenti katolici poznaju te razlike. Jedna od njih, iz područja blagdana, je svakako krsna slava. ${ }^{44}$ To je pravoslavni blagdan posvećen zaštitniku obitelji. Od pravoslavaca slave je Srbi, Crnogorci i Makedonci. Održavaju je izravni muški potomci. Zanimljivo da su u Boki Kotorskoj, u XX. stoljeću, živjeli Srbi-katolici koji su slavili slavu kao i pravoslavni. Pretpostavlja se da je riječ o Srbima-pravoslavcima koji su pod pritiskom venecijanskih vlasti prešli na katoličanstvo, ali se nisu htjeli odreći svoje obiteljske slave. Pored njih, krsna slava se obilježavala i kod katolika u Albaniji, na Kosovu (Janjevo i Letnica). U postsocijalizmu je "obnovljena" proslava krsne slave. ${ }^{45}$ Da je danas slave pravoslavni zna $89,3 \%$ studenata katolika; 73,8 \% studenata društvenih; 61, $2 \%$ studenata tehničkih nauka; 84,2\% studenata teologije.

Ni pravoslavni svećenici, kao ni katolički, ne mogu se ženiti. Naime, svećenički kandidati su dužni, prije hirotonije ili rukopoloženja za svećenika, oženiti se (u slučaju smrti supruge, ne mogu se drugi put oženiti). Dakle, mogu se oženiti dok su svećenički kandidati, ali ne kao i svećenici. Celibat je ostao samo kod redovnika, monaha, koji žive u manastirima. Da manastirom upravlja iguman znalo je ukupno 31,3\% ispitanika. ${ }^{46}$ Studenti katolici su iznad tog prosjeka: $46,4 \%$ ih je znalo točan odgovor kao i $32,7 \%$ studenata društvenih; $18,4 \%$ tehničkih nauka, te $68,4 \%$ studenata teologije.

Da je "Pomoz Bog" pozdrav među pravoslavnima zna 85,7 \% studenata katolika; 77,8 \% studenata društvenih nauka; $51,0 \%$ studenata tehničkih nauka, te $94,7 \%$ studenata teologije.

Kojih deset osobina - od navedenih 24 - su izdvojili studenti katolici da odlikuju pripadnike pravoslavlja: ekstremni nacionalisti (12,5\%), duhoviti (14,3\%), prevrtljivi (10.7\%), naivni $(8,9 \%)$, impulzivni $(8,9 \%)$, temperamentni $(8,9 \%)$, muzikalni $(7,1 \%)$, snalažljivi $(7,1 \%)$, tolerantni $(5,4 \%)$, koristoljubivi $(5,4 \%)$.

$\mathrm{Pa}$ ipak, 69,6 \% studenata katolika izjavljuje da poštuje pravoslavne (studenti pravoslavni katolike 50,7 \%), da "nemaju ništa protiv njih" 26,8 \%, "ne volim ih" 3,6 \% (6,3\% studenata pravoslavnih ne voli katolike).

\footnotetext{
44 "Novembar je mesec slava, koje počinju krajem oktobra i završavaju posle Srpske nove godine, januara meseca. Nema vremena da se radi: ili praviš slavu, ili odlaziš nekome na slavu." (Komac, 2012: 550) 45 "Zaustavljena je obnova religioznosti u našoj crkvi. Narod se vraća krsnoj slavi, paljenju badnjaka, daćama na pogrebima, ali ne i pravom verovanju" (Ekmečić, 2018: 184).

${ }^{46}$ Najviše ih je (48,9 \%) odgovorilo "Ne znam", 5,2 \% da upravlja episkopijom i 4,0 \% parohijom.
} 
Da s pravoslavnim: mogu biti drug/arica izjavljuje $82,1 \%$ studenata katolika; susjed/komšija 73,2 \%; može ga imati za šefa 58,9 \%; kao nastavnika svoje djece 51,8 \%; kao kućnog prijatelja 71,4\%; imati za zeta/snahu 21,4 \%.

Kada je riječ o nazivima religijskih vođa koji pripadaju pravoslavlju 48,2 \% studenata katolika zna da su to nazivi paroh; vladika - 58,9 \% (čak više nego studenti pravoslavni - 57,7 \%); mitropolit - 51,8 \%; patrijarh - 58,9\%.

\section{d) Poznavanje ostalih religija}

Pored pravoslavne, islamske, židovske i katoličke vjerske zajednice, ispitanici su najčešće spominjali da u Bosni i Hercegovini djeluju jehovini svjedoci, evangelisti i baptisti. Zanimljivo je da ih je 3,2\% navelo i ateiste kao pripadnike vjerske zajednice. Studenti katolici su naveli baptiste, evangeliste, jehovine svjedoke, Hare-Krišna, grkokatolike (zanimljivo nisu naveli starokatolike). Oni koji kažu "nisam vjernik" navodili su jehovine svjedoke. Kod sviju je bilo navođeno religijskih grupa koje nisu ni prisutne u Bosni i Hercegovini.

Zanimalo nas je mišljenje ispitanika o odnosu prema pripadnicima sljedbi/ sekti i novih religijskih pokreta. Da pripadnicima sljedbi i novih religijskih pokreta treba onemogućiti djelovanje smatra 42,9\% studenata katolika; nešto su odlučniji u stavu da ih treba onemogućiti u djelovanju studenti društvenih nauka $(34,0 \%)$ u odnosu na studente tehničkog usmjerenja $(28,6 \%)$; onemogućilo bi ih u djelovanju 42,1\% studenata teologije; da treba ograničiti njihova vjerska prava smatra 19,6 \% studenata katolika; 11,6 \% studenata društvenih nauka; 8,2 \% studenata tehničkih nauka; $18,4 \%$ studenata teologije; osigurati im iste slobode kao i pripadnicima drugih religijskih zajednica kaže 16,7 \% studenata katolika; 13,2\% studenata teologije.

Inače, 17,9 \% studenata katolika izjavljuje da poštuje pripadnike sljedbi, $46,4 \%$ nema ništa protiv njih, ali ih ne voli $21,4 \%$ i čak mrzi 3,6 \%.

Što studenti katolici misle o ateistima?

Prema popisu stanovništva Bosne i Hercegovine iz 2013. godine, ateista i agnostika bilo je ukupno 38.669 ili 1,09\%. U Republici Srpskoj ih je bilo 0,4 $\%$, u Federaciji 1,39 \%. Prema popisu iz 1991. godine ateista je bilo 5,73 \%. Tako, dok u svijetu raste broj ateista i nereligioznih ${ }^{47}$, u Bosni i Hercegovini opada. U našem istraživanju 6,4 \% ispitanika se izjasnilo da "nisu vjernici". Među njima ima zasigurno ateista, agnostika, indiferentnih...

\footnotetext{
47 “Brojke ateista i nereligioznih približavaju se $16 \%$ svjetske populacije. To znači da postoji 1.1 milijardu nereligioznih ljudskih bića, što je malo manje od ukupnog zbroja svih budista i hinduista" (Volf, 2017: 99).
} 
Pošto su ih studenti (i katolici i muslimani i pravoslavni) naveli kao "religiju" koja postoji u Bosni i Hercegovini, zanimalo nas je što oni misle o ateistima. Iznenadilo nas je otkud su date tako loše karakteristike ateistima kad ih u društvu (prema popisu stanovništva iz 2013. godine) ima svega 1,09 $\%$ i u javnosti se uopće ne oglašavaju.

Ateisti su za studente katolike: praznovjerni (17,9\%), naivni (12,5\%), koristoljubivi (10,7\%), nepristupačni $(7,1 \%)$, neobrazovani $(7,1 \%)$, lukavi (7,1\%), materijalisti $(7,1 \%)$, primitivni $(5,4 \%)$, škrti $(5,4 \%)$, i iznenađujuće - veoma religiozni 5,4 \% (znaju li ovih 5,4 \% studenata katolika uopće što znači riječ ateista?).

Inače, ateiste i agnostike poštuje $35,1 \%$ ispitanika, nemaju ništa protiv njih $36,5 \%$, ne vole ih $18,8 \%$ i $0,2 \%$ ih mrzi.

Ne vole ih ili mrze 21,3\% studenata društvenih nauka i 24,4\% studenata tehničkih nauka. Otkud to? Zašto? Tko je kod njih izgradio i kakvu sliku o ateistima? Sve su to pitanja za neka druga istraživanja.

Kakav odnos prema njima imaju studenti katolici? Sa ateistom/agnostikom mogu biti: drug/arica 50,0 \% (58,0 \% studenata društvenih i 42,9 \% studenata tehničkih usmjerenja, te 52,6\% studenata teologije); imati za susjeda/ komšiju 50,0 \% (57,3 \% studenata društvenog i 38,8 \% tehničkog usmjerenja, te $57,2 \%$ studenata teologije); imati za šefa $37,5 \%$ (48,2 \% studenata društvenog i 34,7 \% tehničkog usmjerenja); imati za poslovnog partnera 51,8 \% (53,6 \% studenata društvenog i 42,9\% tehničkog usmjerenja); za nastavnika svoje djece 35,7 \% (46,9 \% studenata društvenog i 36,7 \% tehničkog usmjerenja, te 34,2\% studenata teologije); za kućnog prijatelja 44,6 \% (48,4\% studenti društvenog i $38,8 \%$ oni tehničkog usmjerenja, te $42,1 \%$ studenata teologije); za zeta/snahu 16,1 \% (32,9 \% studenata društvenog i 28,6 \% onih tehničkog usmjerenja, te 15,8\% studenata teologije). Od 58,0\% studenata katolika koji bi mogli imati ateistu za druga/ricu, postotak se smanjio na 16,1 $\%$ ispitanika koji bi imali ateistu za zeta/snahu. Naravno, ovo su samo stavovi o zamišljenoj situaciji. Kad bi se u stvarnosti našli u takvoj situaciji pitanje je bi li procent bio još niži.

Inače, ispitanici koju su se samoodredili da nisu vjernici pokazali su se informiranijim u mnogim pitanjima o religijama u odnosu na studente muslimana i studente pravoslavne, a u nekim pitanjima i od studenata katolika. ${ }^{48}$

\footnotetext{
${ }^{48}$ Bolje su od studenata muslimana i od studenata pravoslavnih znali navesti koje religije spadaju u abrahamske (40,6 \% ih); više od studenata muslimana su znali koja je najrasprostranjenija kršćanska molitva $(78,1 \%)$ i koji je najvažniji kršćanski blagdan (37,5 \%); da je križ simbol kršćanstva poznatije im je nego studentima muslimanima (87,5); znaju više od studenata muslimana (35,5\%) da se Biblija sastoji od Starog i Novog zavjeta (71,9 \%); da Jeruzalem ima izuzetnu važnost za pripadnike sve tri
} 
Otkud to kad nisu pohađali vjeronauku, ili su, možda pohađali kulturu religija (koja se izvodi u nekim školama)? U upitniku nismo imali pitanja koja bi nam dala na to odgovor.

\section{Pokazatelji (ne) uvažavanja različitosti}

Hram neke druge vjeroispovijesti posjetilo je 28,6 \% studenata katolika kao gost, 16,1 \% iz radoznalosti, 21,4 \% kao turisti (ukupno 66,1\%). Neusporedivo je više studenata društvenog usmjerenja (65,6 \%) posjetilo hram neke druge vjeroispovijesti u odnosu na studente tehničkog usmjerenja $(36,8 \%)$, i 81,6\% studenata teologija posjetilo je hram neke druge religijske zajednice.

Na pitanje "Da li Vam je poznato da je pripadnik druge vjerske zajednice posjetio vjerski objekt Vaše religijske zajednice", od studenata katolika dobili smo sljedeće odgovore: 35,7 \% kaže "da, kao moj gost", 35,7 \% "kao turista".

"Hram je vidljiva religija, ali unutar svojih zidina krije i druga, nevidljiva značenja" (Šušnjić, 2008: 62). Nismo pitali ispitanike kako bi se trebali ponašati prilikom posjete džamiji ili pravoslavnoj crkvi. Kad bismo imali umjesto vjeronauke u javnim školama Kulturu religija onda bi zasigurno bili educirani u tome.

"Pripadnici svake religije često su ubeđeni da je jedino njihova istinska. Možda pripadnici jedne od njih i jesu u pravu”, piše Harari (2018: 230). Osobno sam skeptičan prema svakoj osobi, ili tradiciji, koja smatra da jedino ona posjeduje "istinu". ${ }^{49}$ Pitali smo pravoslavne i katolike u kojoj se mjeri

\footnotetext{
abrahamske religije znalo ih je više $(90,6 \%)$ nego studenti muslimani $(61,8 \%)$ ili studenti pravoslavni (77,5 \%); više ih u odnosu na studente muslimane (24,7 \%) zna tko su autori četiriju evanđelja $(40,6 \%)$ ili koje se godine kršćanstvo podjelilo na zapadno i istočno (38,2 \% studenti muslimani; 59,4\% studenti "nisam vjernik"). Neuporedivo ih više $(28,1 \%)$ u odnosu na studente pravoslavne $(4,9 \%)$ i studente muslimane $(9,6 \%)$ zna da su franjevci najpoznatija redovnička zajednica u Bosni i Hercegovini; nešto bolje i od studenata muslimana $(86,1 \%)$ i studenata pravoslavnih $(71,4 \%)$ znaju da katolici nedjeljom odlaze na misu (81,3\%); najupućeniji su od svih studenata da su Sefardi u Bosnu i Hercegovinu došli iz Španjolske (46,9 \%); više od studenata muslimana (50,2 \%) znaju da je Bog Deset zapovijedi saopćio Mojsiju (75,0 \%); više im je poznato da je Pesah židovski blagdan u čast izlaska iz egipatskog ropstva $(43,8 \%)$ u odnosu na studente muslimane $(16,7 \%)$ i studente pravoslavne $(26,1 \%)$; više nego pripadnici abrahamskih religija znaju da je naziv židovskog hrama sinagoga $(75,0 \%)$ kao i da je Davidov znak simbol židovske religije (56,2 \%); daleko ih je više posjetilo hram neke druge religijske zajednice $(71,9 \%)$ u odnosu na studente katolike $(66,1 \%)$, studente muslimane $(67,7 \%)$ ili studente pravoslavne $(47,9 \%)$.

49 "Kad je u pitanju bratstvo, religije nisu od neke pomoći. U pogledu ljubavi nprema bližnjem koju one propovedaju, nikad im ne pođe za rukom da budu verodostojne, zato što onaj ko tvrdi da poseduje apsolutnu istinu ne može a da druge ne smatra zabludelim." (Galimberti,2018:460)
} 
slažu sa tvrdnjom "Kršćanstvo je jedina istinita vjera"50: 67,8 \% studenata katolika se slažu ("potpuno se slažem" 58,9 \% i “djelomično se slažem" 8,9 \%) s tvrdnjom kako je "kršćanstvo jedina istinita vjera". Samo su studenti muslimani izričitiji da je njihova vjera jedina istinita (81,3\%). Pravoslavni se u $45,1 \%$ slučajeva slažu (28,2 \% potpuno i $16,9 \%$ djelomično) s tom tvrdnjom. I 77,7 \% studenata katoličkih i pravoslavne teologije se "potpuno" ili "djelomično" slaže sa ovom tvrdnjom.

Pitali smo ispitanike koliko se slažu s tvrdnjom da kršćani i muslimani vjeruju u istog Boga? S tvrdnjom se "potpuno slaže" 25,0 \% studenata katolika i "djelomično se slaže" 21,4 \% (ukupno 46,4 \%). Zanimljivo da se samo 34,2 \% studenata teologije "potpuno" ili "djelomično" slaže s navedenom tvrdnjom.

\section{Iskustvo života s pripadnicima drugih religija}

Liberalna tolerancija svodi se na zahtjev da te onaj Drugi ne smeta. Ona pati od straha da može biti povrijeđen bilo čiji religijski osjećaj. "Dvije teme koje određuju tolerantan i liberalan stav današnjice u odnosu na Druge: respektiranje drugačijeg, otvaranje prema njima uz opsesivan strah od smetanja. Ukratko, Drugi je dobar u mjeri u kojoj njegova prisutnost nije nametanje, odnosno u mjeri u kojoj Drugi ili Drugo nije istinski Drugo." ${ }^{51}$

U svijetu se štuje četiri tisuće bogova. Koji je pravi? “Tu se radi o tržištu ideja, a i Crkva je na neki način na tržištu. Crkva je jedna ozbiljna korporacija i jedan vrlo ozbiljan biznis." ${ }_{2}$ Suvremena kultura nalaže dijalog s Drugima jer u "Drugome ima nešto od nas, a u nama nešto od Drugoga", piše Amin Maalouf (Maluf, 2017: 242). To je moguće u toleranciji koja "nastaje tek kad naučimo prihvaćati da Drugi žive drugačije od nas i imaju pravo na to." (Graus, 2018: 56)

Za razvoj tolerancije važno je i kako se odnosimo prema svojoj i religiji Drugoga. Na pitanje "Koliko se osjećate pripadnikom svoje religije"53, studenti katolici odgovaraju: "u potpunosti" 87,5 \% i "djelomično" 10,7 \% .

\footnotetext{
50 "Pogreška koju rade mnogi religiozni ljudi jest da smatraju da ono u što vjeruju mora biti istina" britanski genetičar Steve Jones u intervju "Jutarnji list", Zagreb, 16. 6. 2013:44.

${ }^{51}$ Slavoj Žižek, Vjera u strast lišena kofeina, v. "Hrvatska ljevica" 31. 8. 2004., str. 31.

${ }^{52}$ Borut Šeparović, u intervjuu tjedniku "Exspres", Zagreb, 8. 2. 2019: 48.

53 "Naše vezivanje za vlastitu veru ne može proisteći iz univerzalnog pregleda svih drugih vera, na osnovu kojeg bismo zaključili da je vera za koju smo se opredelili ispravna. Ono može proizaći jedino iz našeg osećanja njene unutrašnje snage, koje se učvršćuju u suočenju sa izazovima koja dolaze iz drugih vera na koje moramo odgovoriti”, piše Ch. Taylor (Tejlor, 2011: 688).
} 
Slijedilo je pitanje: "U kojoj mjeri se osjećate bliskim sa ostalim pripadnicima svoje religije", studenti katolici odgovaraju: "u potpunosti" 35,7 \%, "djelomično" 53,6 \% .

Studenti katolici smatraju da im je važno $(87,5 \%)$ ili djelomično važno $(8,9 \%)$ što su pripadnici svoje religije (ukupno: $96,4 \%){ }^{54}$

Kada netko tko nije pripadnik Vaše religije kritizira pripadnike Vaše religije, u kojoj mjeri se osjećate lično/osobno kritiziranim? To doživljava kao ličnu/osobnu kritiku 23,2 \% studenta katolika; djelomično doživljava kao osobnu/ličnu kritiku 30,4 \%; to ne doživljavam kao osobnu kritiku 37,5 \%.

Da kršćani i muslimani mogu živjeti zajedno, imajući svatko svoju vjeru (prema popisu iz 2013. godine 96,1 \% stanovnika Bosne i Hercegovine pripada tim dvjema religijama) 39,3 \% studenata katolika se "potpuno" i 23,2 \% "djelomično" slaže s navedenom tvrdnjom (ukupno: 62,5 \%).

Željeli smo znati kakvo je osobno iskustvo studenata katolika sa vjernicima drugih vjeroispovijesti. Polovina (50,0 \%) navodi da ima u susjedstvu obitelj druge vjeroispovijesti i da su odnosi dobri. Slijedi odgovor da u bližoj rodbini ima pripadnika druge vjeroispovijesti i odnosi su dobri - izjavljuje $26,8 \%$ studenata katolika; dok ih 17,9\% ima iskustvo s osobom druge vjeroispovijesti na "radnom mjestu" i iskustvo je pozitivno. Nema nikakvo iskustvo s osobom druge vjeroispovijesti 14,3\% studenata katolika.

Zanimalo nas je da li rodbini, susjedima i prijateljima drugih vjeroispovijesti čestitaju njihove blagdane i pozivaju li ih na vjerske i druge svečanosti u svoj dom. Najviše ih (43,3 \%) izjavljuje da čestita, odlazi, poziva i proslavlja s njima sve svetkovine ne opterećujući se razlikama (44,6\%). Potom slijedi 48,2 \% ispitanika koji samo čestitaju telegramom, SMS porukom i sl. bez zajedničkog slavlja. Je li ovo najčešći oblik blagdanske komunikacije?

Još uvijek u Bosni i Hercegovini ima rodbinskih veza između pripadnika različitih nacionalnosti: $21,4 \%$ ispitanika izjavljuje da je netko iz njegove uže obitelji u braku s pripadnikom/com druge nacije.

Zanimalo nas je i kako studentska populacija gleda na međureligijske odnose. Najviše ih (32,3 \%) smatra da se odnosi među religijama pogoršavaju i ako se ovako nastavi doći će do novih ratova; $22,4 \%$ ih smatra da religije nisu svjesne koliko su im danas važni međusobni odnosi i da bez suradnje

\footnotetext{
${ }^{54}$ Pew Rescarch Center proveo je 2019. istraživanje kojim je obuhvatio 38.426 ispitanika u 34 zemlje, prema kojem se bilježi pad o odnosu na pitanje "Igra li Bog važnu ulogu u njihovom životu", u odnosu na 1991. godinu. U Poljskoj je tada pozitivno odgovorilo 83 \% ispitanika, 2019 - 69 \%; u Italiji je zabilježen pad sa $81 \%$ na $60 \%$; Španjolskoj sa $71 \%$ na 45 \%. Porast je zabilježen u Rusiji sa 40 \% na 56 $\%$ i Ukrajini sa 50 \% na 62 \%. (Izvor: Većina u Europi ne povezuje vjeru u Boga i moralnost, "Jutarnji list”, Zagreb, 25. 7. 2020: 17).
} 
ne mogu vršiti svoju misiju. Tek 13,6 \% ih smatra da religije danas sve više uklanjaju međusobna neprijateljstva i nepovjerenje. Nije zanemariti ni to da ih $23 \%$ zaokružilo odgovor "Ne znam".

Kriza je bitna za razvoj religije, a nema čovjeka koji se u svom životu ne susreće sa krizama i stresovima. Indikatori koji upućuju na zaključak o krizi u Crkvi: opada broj svećenika ${ }^{55}$; stotine svećenika svake godine traže prelazak u laike kako bi se mogli vjenčati; opada broj onih koji odlaze na misu ${ }^{56}$; opada broj crkvenih vjenčanja; razlika između stavova Crkve i života vjernika (po pitanju pobačaja, seksualnosti, kontracepcije...), pad povjerenja u Crkvu kao instituciju. Martel (2019) smatra da se ljudi udaljavaju od Crkve jer ona ne ide u korak s vremenom, zbog ultrakonzervativnih stavova o braku, pravima žena, pravima homoseksualaca, prezervativima i AIDS-u; zbog seksualnog zlostavljanja i zaštite koju su uživale stotine svećenika pedatora.

Ponudili smo ispitanicima više odgovora i zamolili ih da zaokruže ono što im se čini točnim (uz mogućnost više odgovora). Najviše ih se složilo s tim da su religije danas u krizi zato što čovjek iz temelja mijenja svoj odnos prema Bogu (40,9 \%); 18,6 \% ih smatra da su religije danas u krizi zbog sekularnih ideologija i sljedbi koje "spretno zavode mlade"; 17, 4 \% ih smatra da su religije u krizi jer su popustile modi i iskušenjima koje nudi bezbožni život; 16,8 $\%$ ih smatra da su religije u krizi jer ne uspijevaju odgovoriti suvremenim ljudima na njihove vjerske potrebe; $14,8 \%$ ih smatra da su religije u krizi zbog potrošačkog načina života. Samo 5,8 \% ispitanika smatra da religije danas nisu u krizi (Bez odgovora - 17,4 \%).

\section{Kako katolike doživljavaju studenti muslimani}

Vidjeli smo koje su "slabe točke" kod studenata katolika o poznavanju islama i muslimana. A koje su "slabe točke" studenata muslimana kad je u pitanju poznavanje kršćanstva i katoličanstva. Bibliju u svom domu posjeduje $8,8 \%$ studenata muslimana, a da ju je čitalo izjavljuje njih $15,1 \%$. S druge strane $17,9 \%$ studenata katolika je izjavilo da u domu posjeduju Kur'an, a $25,0 \%$ da ga je i čitalo. Prema ovom indikatoru, studenti katolici imali su veće šanse za upoznavanje islama nego studenti muslimani da upoznaju kršćanstvo. Dok 26,8 \% studenata katolika zna da se poglavlja koja sačinja-

\footnotetext{
55 "U Francuskoj svake godine umire otprilike 800 svećenika, a manje od sto ih se zarazi ...Katoličanstvo polako izumire." (Martel, 2019: 516)

56 "Ljudi danas ne idu često na misu i čine se sretnima bez Boga", kaže kardinal Walter Kasper (Prema: Martel, 2019: 123).
} 
vaju Kur'an nazivaju sure, i 35,5\% studenata muslimana zna da se Biblija sastoji od Starog i Novog zavjeta. Također, 24,7 \% ih je znalo da su Matej, Marko, Luka i Ivan autori četiriju evanđelja.

Da obrezanje ne spada u sedam sakramenata zna 43,8 \% studenata muslimana; da tu ne spada ni misa/liturgija zna ih $10,0 \%$, a pomazanje navodi njih $20,3 \%$.

Među religijske vođe Katoličke Crkve, 39,4 \% studenata muslimana navodi župnika; 33,9 \% biskupa; 45,0 \% papu. Također, 68,5 \% studenata muslimana je znalo da je "Oče naš" najrasprostranjenija kršćanska molitva. Tek ih je 12,0 \% znalo da je Uskrs/Vaskrs najznačajniji kršćanski blagdan (91,1 \% studenata katolika znalo je da Ramazanski bajram i 87,5 \% Kurbanbajram spadaju u dva najpoznatija blagdana kod muslimana). Vidimo da su studenti katolici daleko informiraniji o vjerskim blagdanima muslimana, nego obrnuto.

Dok je 32,2 \% studenata katolika znalo da je polumjesec sa zvijezdom simbol islama, 78,5 \% studenata muslimana zna da je križ simbol kršćanstva. Da katolici nedjeljom idu na misu znalo je $86,1 \%$ studenata muslimana, a 60,8 \% studenata katolika znalo je da muslimani petkom odlaze na džumu. Prema ova dva posljednja pokazatelja studenti muslimani su informiraniji o religiji svojih susjeda, nego obrnuto.

Da je franjevački red najpoznatiji od katoličkih redovničkih zajednica u Bosni i Hercegovini zna 9,6 \% studenata muslimana. Rekli bismo, iznenađujuće malo. Nešto malo više ih zna (14,7 \%) zna da gvardijan upravlja samostanom.

Dok 92,9\% studenata katolika zna kojim se pozdravom pozdravljaju muslimani, to zna $72,9 \%$ studenata muslimana za međusobni pozdrav katolika.

Studenti muslimani katolike doživljavaju kao: muzikalne $(10,4 \%)$, koristoljubive $(7,2 \%)$, temperamentne $(6,4 \%)$, lukave $(5,6 \%)$, konzervativne $(5,2 \%)$, snalažljive $(4,8 \%)$, materijaliste $(4,8 \%)$, ekstremne nacionaliste $(4,4$ $\%)$, inteligentne $(4,4 \%)$, veoma religiozne $(4,4 \%)$.

Studenti muslimani izjavljuju da poštuju katolike (66,5 \%), da nemaju ništa protiv njih $(24,7 \%)$ a $2,4 \%$ da ih ne voli.

Studenti muslimani izjavljuju da s katolikom mogu biti: drug/arica 72,9 \% (studenti katolici s muslimanima 67,9\%); susjed/komšija 69,3 \% (studenti katolici s muslimanom 55,4\%); imati ga za šefa 53,8\% (studenti katolici muslimana $37,5 \%$ ); imati ga za poslovnog partnera $61,4 \%$ (studenti katolici muslimana 50,0 \%); imati ga za nastavnika svoje djece 57,8 \% (studenti katolici muslimana 37,5\%); kao kućnog prijatelja 60,2 \% (studenti katolici musli- 
mana 55,4 \%); imati za zeta/snahu 37,5\% (studenti katolici muslimana 16,1 $\%$ ). Prema ovim podacima studenti muslimani su daleko tolerantniji prema katolicima nego studenti katolici prema muslimanima.

\section{Kako katolike doživljavaju studenti pravoslavni}

Izdvojili smo nekoliko pokazatelja o tome kako katolike doživljavaju studenti pravoslavni. Da s katolikom mogu biti: drug/arica izjavljuje ih 70,4 \% (82,1\% studenata katolika to izjavljuje za pravoslavne); susjed/komšija 67,6 $\%$ (73,2 \% studenti katolici s pravoslavnim); imati ga za šefa 48,3 \% (58,9\% studenata katolika za pravoslavne); imati ga za poslovnog partnera 57,0 \%; imati ga za nastavnika svoje djece 47,9\% (51,8 \% katolika za pravoslavne); kao kućnog prijatelja 55,6 \% (71,4 \% studenta katolika za pravoslavne); imati za zeta/snahu 34,5 \% (21,4 \% studenta katolika za pravoslavnog).

Izuzev posljednjeg pokazatelja (21,4 \% ih prihvata da za zeta/snahu imaju pravoslavne), u svim drugim pokazateljima studenti katolici se pokazuju tolerantnijim prema pravoslavnima, nego obratno. Iako katolici i pravoslavni pripadaju istoj religiji (kršćanstvu), te bi za bilo očekivati veću razinu međusobnog poznavanja i uvažavanja, zanimljivo je da su studenti muslimani iskazali daleko tolerantnije stavove prema katolicima od studenata pravoslavnih.

Da je franjevački red najpoznatiji od katoličkih redovničkih zajednica u Bosni i Hercegovini znalo je svega 4,9 \% studenata pravoslavnih. Svi najpoznatiji franjevački samostani i obje provincije nalaze se u Federaciji. Treba li tu tražiti objašnjenja za ovako slabo poznavanje te problematike među studentima pravoslavnima? Zar im na vjerskoj pouci ne govore baš ništa o značaju franjevačkih samostana u kulturnom životu Bosne i Hercegovine (muzeji, knjižnice, numizmatičke zbirke...). Ipak, 12,7 \% ih zna da gvardijan upravlja franjevačkim samostanom. Neusporedivo bolje su upoznati s tim da je "Hvaljen Isus i Marija!" pozdrav među katolicima $-87,3 \%$ ih je to znalo (Približno isto, 85,9 \% studenata katolika znalo je da je "Pomoz Bog!" pozdrav među pravoslavnima).

Deset osobina koje su najviše izdvojili studenti pravoslavni o katolicima su: materijalisti (16,9\%), prevrtljivi (12,7\%), škrti (10,6 \%), veoma religiozni (9,9\%), privrženi obitelji (9,9\%), lukavi (9,9\%), koristoljubivi (9,2 \%), tolerantni (8,5\%), ekstremni nacionalisti (7,7\%), impulzivni (7,0\%).

Katolike poštuje $65,3 \%$; nemaju ništa protiv njih $26,3 \%$, ne vole ih 3,0 \% i mrze ih $0,2 \%$. Je li onda u pravu Rene Remon kad piše da religijska razlika 
između pravoslavnih i katolika u ex. Jugoslaviji postaje dodani element razlozima za mržnju između Srba i Hrvata (Remon, 2017)?

Iako su pripadnici iste religije kao i katolici (kršćanstva), manje ih poštuju, a više ne vole od studenata muslimana.

\section{ZAKLJUČAK}

U pravu je Galimberti kad piše da "danas ne možemo biti ljudi ako ostanemo zatvoreni unutar uskih granica sopstvene tradicije" (2018: 458). U ovoj analizi pokušali smo utvrditi kakvo je suočavanje s različitošću studenata katolika (ali i ostalih studenata).

Jesu li studenti katolici najreligiozniji, najeduciraniji u svojoj religiji i o religiji svojih susjeda muslimana i židova?

Je li studenti muslimani najmanje znaju o religijama svojih susjeda? O tome nešto više u tekstu Dine Abazovića. Zanimljivo da oni koji za sebe kažu "nisam vjernik" su informiraniji o religijama - mnoge činjenice o religijama svojih susjeda znaju bolje od katolika, a osobito od muslimana i pravoslavnih (pogledati fusnotu br. 43).

Studenti/ce koji žive u gradu manje pohađaju vjeronauk, manje vjeruju u postojanje Boga, više su posjetili hram druge religije.

Može li se reći da su studenti društvenih nauka više informirani o religijama i religijskom životu svojih sugrađana od studenata tehničkih nauka (osim u vjerovanju u postojanje duše, zagrobnog života, raja). Studenti društvenih nauka su informiraniji o rangu religijskog vodstva u islamu, o tome od kada se računa muslimanska godina, koje godine se kršćanstvo podijelilo na istočno i zapadno, nazivima religijskih vođa u katoličkoj, islamskoj i pravoslavnoj zajednici. Otkud tolike razlike o znanju o religiji svojih sugrađana između studenata društvenih nauka i onih koji studiraju tehničke znanosti kad su i jedni i drugi pohađali vjeronauk? Ima li to ikakve veze s tim da je sociologija potpuno izbačena s tehničkih fakulteta, trebalo bi istražiti. Čak bi trebalo "da jedan diplomirani inženjer, biolog, bankarski stručnjak, bude u stanju da se pokaže kao pametan sagovornik o temi religioznih razlika i s tim u vezi navikama i običajima, o temi promena u porodici i složenom društvu, o kontroli seksualnosti, o budućnosti mladih." (Galimberti, 2018: 455)

$\mathrm{Na}$ osnovu ovog istraživanja moglo bi se zaključiti da studentska populacija u Bosni i Hercegovini, iako je prošla vjeronauk u javnim školama, vrlo malo, u nekim segmentima gotovo nikako, poznaje religiju svojih susjeda Židova. Ovako nepoznavanje religije svojih susjeda opravdava zagovaranje 
da se u javne škole, umjesto (ili barem uz) vjeronauke, uvede Kultura religija (ne pouka u religiji, već pouka o religijama). Tako bi mladi naraštaji bili više informirani o religijskoj kulturi svojih sugrađana.

Inače, nakon ovakvih rezultata istraživanja postavlja se pitanje nisu li religije (konfesije) još uvijek "ležeći policajci" (Harari) na putu ka integraciji bosansko-hercegovačkog društva? Hoće li one biti ishodišta nesloge i razjedinjavanja ili biti ujedinjavajuća društvena sila? Teorijski to ne izgleda tako, ali je teorija, u ovom slučaju, šuplja kao sito.

\section{Literatura:}

Ali, Ayaan Hirsi (2016). Zašto je islamu nužna reforma. Ljevak. Zagreb.

Anižar, Gil (2014). Semiti, rasa, religija, književnost. Centar za medije i komunikacije. Beograd.

Adendt, Hannah (2019). Ljudi u mračnim vremenima. TIMpress. Zagreb.

Armstrong, Karen (2012). U prilog Bogu. Ljevak. Zagreb.

Assmann, Jan (2010). Mojsije Egipćanin. Antibarbarus Zagreb.

Bojić, Drago (2016). Zlato i tamjan. Centar za kritičko mišljenje. Mostar.

Bugarski, Ranko (2005). Jezik i kultura. XX vek. Beograd.

Chouragui, Andre (2005.). Deset zapovijedi danas. Konzor. Zagreb.

Dawkins, Richard (2007.). O Bogu. Izvori. Zagreb.

Dokins, Ričard (2009). Đavolov kapelan. Heliks. Smederevo.

Eco, Umberto (2011) u: Karijer, Ž.K.-Eko. Ne nadajte se da ćete se rešiti knjiga. Gradac. Čačak.

Ekmečić, Milorad (2018). Pečat Milorada Ekmečića. Novosti. Beograd.

Ervije-Leže, Danijela (2009). Prenošenje religioznih identiteta, u zborniku: Identitet(i). Clio. Beograd.

Galimberti, Umberto (2018). Mitovi našeg vremena. Izdavačka knjižarnica Zorana Stojanovića. Novi Sad.

Gogolj, Nikolaj Vasiljević (2004). Mrtve duše. Jutarnji list. Zagreb.

Graus, Karl-Markus (2018). Europa - neotkriveni kontinent. Fraktura. Zagreb.

Harari, Juval (2018), Homo deus: kratka istorija sutrašnjice. Laguna. Beograd.

Harari, Juval (2019). 21. lekcija za 21. vek. Laguna. Beograd.

Harari, Juval (2019a). Sapiens: kratka historija čovečanstva. Laguna. Beograd.

Hefe, Otfrid (2016). Da li je demokratija sposobna za budućnost? Akademska knjiga. Novi Sad.

Imamović, Emir (2018). Terorist. V.B.Z. Zagreb.

Ivanji, Ivan (2018). Poslednji potez. Laguna. Beograd.

Janos, Hristo (2014). Crkva u postkomunističkoj Evropi. Centar za istraživanje pravoslavnog monarhizma. Beograd.

Jergović, Miljenko-Basara, Svetislav (2015). Drugi krug. Laguna. Beograd.

Jergović, Miljenko (2017). Nezemaljski izraz njegovih ruku. Fraktura. Zagreb.

Jović. Dejan (2017). Rat i mit. Fraktura. Zagreb.

Karijer, Ž.K.-Eko, U. (2011). Ne nadajte se da ćete se rešiti knjiga. Gradac. Čačak.

Knežević, Nikola (2012). Savremena politika teologija na Zapadu. Otačnik. Beograd. 
Komac, Miran (2012). Pogled jednog Slovenaca na nišlijske krčme u zborniku: Kafanologija /ur. Dragoljub Đorđević/. Službeni glasnik. Beograd.

Krleža, Miroslav (2009). Mnogopoštovanoj gospodi mravima. Naklada Ljevak. Zagreb.

Kuschel, Karl-Josef (2011). Židovi - kršćani - muslimani. Svjetlo riječi. Sarajevo.

Maluf, Amin (2017). Fotelja na Seni. Laguna. Beograd.

Markešić, Ivan (2012). Hrvatska i Bosna i Hercegovina na Križu života. Synopsis,. ZagrebSarajevo.

Metz. Johann Baptist (2011) /ur./. Krajolik od krikova. Ex libris. Rijeka.

Remon, Rene (2017). Religija i društvo u Evropi: sekularizacija u XIX i XX veku 1789-2000. Akademska knjiga. Novi Sad.

Sbutega, Branko (2006). Kurosavin nemir svijeta. Akvarius. Beograd.

Sioran, Emil (2011). Suze i sveci. Braničevo. Požarevac.

Smith, Anthony (2003). Nacionalizam i modernost. Fakultet političkih nauka. Zagreb.

Stanley, Jason (2018). Kako funkcionira fašizam. 24 sata d.o.o. Zagreb.

Stern, Horst (1993). Čovjek iz Apulije. August Cesarec. Zagreb.

Šušnjić, Đuro 2008). Nedovršen razgovor. Čigoja štampa. Beograd.

Šušnjić, Đuro (2018). Religija i religijska ideologija, u: Zbornik: Mir i pomirenje I. CEIR. Novi Sad.

Tejlor, Čarls (2011). Doba sekularizacije. Službeni glasnik. Bograd.

Todorov, Tzvetan (2017). Osvajanje Amerike - pitanje drugoga. Pelago. Zagreb.

Tokarczuk, Olga (2019). Knjige Jakubove. Fraktura. Zagreb..

Ugrešić, Dubravka (2019). Doba kože. Fraktura. Zagreb.

Ulicka, Ljudmila (2018). Jakovljeve ljestve. Fraktura. Zagreb.

Volf, Miroslav (2017). Pod istim krovom. Ex Libris-Synopsis. Rijeka-Sarajevo.

Zeler, Florijan (2015). Opčinjenost najgorim. Booka. Beograd.

Young, Paul (2018). Laži o Bogu u koje vjerujemo. Ljevak. Zagreb. 